\title{
Particulate Matter Exposure of Rural Interior Communities as Observed by the First Tribal Air Quality Network in the Yukon Flat
}

\author{
Stanley G. Edwinn ${ }^{1,2}$, Nicole Mölders ${ }^{2,3^{*}}$ \\ ${ }^{1}$ Council of Athabascan Tribal Governments, Fort Yukon, USA \\ ${ }^{2}$ College of Natural Science and Mathematics, University of Alaska Fairbanks, Fairbanks, USA \\ ${ }^{3}$ Geophysical Institute, University of Alaska Fairbanks, Fairbanks, USA \\ Email: *cmoelders@alaska.edu, sedwin@alaska.edu, Stanley.edwin@catg.org
}

How to cite this paper: Edwin, S.G. and Mölders, N. (2018) Particulate Matter Exposure of Rural Interior Communities as Observed by the First Tribal Air Quality Network in the Yukon Flat. Journal of Environmental Protection, 9, 1425-1448. https://doi.org/10.4236/jep.2018.913088

Received: November 4, 2018

Accepted: December 24, 2018

Published: December 27, 2018

Copyright () 2018 by authors and Scientific Research Publishing Inc. This work is licensed under the Creative Commons Attribution International License (CC BY 4.0).

http://creativecommons.org/licenses/by/4.0/

\begin{abstract}
A tribal-owned network of aerosol monitors and meteorological stations was installed at Ts'aahudaaneekk'onh Denh (Beaver), Gwichyaa Zheh (Fort Yukon), Jałgiitsik (Chalkyitsik), and Danzhit Khànląii (Circle) in the Yukon Flats, Alaska. Surface inversions occurred under calm wind conditions due to radiative cooling. In May, local emissions governed air quality with worst conditions related to road and river dust. As the warm season progressed, worst air quality was due to transport of pollutants from upwind wildfires. During situations without smoke or when smoke existed at layers above the surface inversion, concentrations of particulate matter of less than 2.5 micrometer in diameter or less $\left(\mathrm{PM}_{2.5}\right)$ were explainable by the local emissions; 24-h means remained below $25 \mu \mathrm{g} \cdot \mathrm{m}^{-3}$. Absorption of solar radiation in the smoke layer and upward scattering enhanced stability and fostered the persistence of the surface inversions. During smoke episodes without the presence of a surface inversion, daily mean concentrations exceeded $35 \mu \mathrm{g} \cdot \mathrm{m}^{-3}$ often for several consecutive days, at all sites. Then concentrations temporally reached levels considered unhealthy.
\end{abstract}

\section{Keywords}

Summer Surface Inversions in the Yukon Flats, $\mathrm{PM}_{2.5}$ Concentrations in Rural Alaska Villages, First Tribal Air-Quality Network in the Yukon Flats

\section{Introduction}

In February 2007, the Alaska Rural Communities Emission Inventory Report No. SR2007-02-01 [1] that was prepared for the Western Governors' Associa- 
tion, Western Regional Air Partnership, Alaska Department of Environmental Conservation, pointed out that throughout the year, Alaska Interior indigenous villages experience greater particulate matter, aerosol, and gaseous pollutant concentrations than the major cities in Alaska. A recent study on air-quality in Arctic cities (north of $59.99 \mathrm{~N}$ ) reported that the long-term annual mean concentrations of particulate matter of $2.5 \mu \mathrm{m}$ or less in diameter $\left(\mathrm{PM}_{2.5}\right)$ were 21.2 $\mu \mathrm{g} \cdot \mathrm{m}^{-3}, 17.6 \mu \mathrm{g} \cdot \mathrm{m}^{-3}$ and $11.9 \mu \mathrm{g} \cdot \mathrm{m}^{-3}$ at sites in North Pole (city in Alaska, 2232 inhabitants [2]), $12.0 \mu \mathrm{g} \cdot \mathrm{m}^{-3}$ and $11.7 \mu \mathrm{g} \cdot \mathrm{m}^{-3}$ at sites in Fairbanks $(32,751$ inhabitants), and 6.4 in Anchorage (298,192 inhabitants) [3]; highest concentrations occurred during winter under surface inversion conditions and in summer when these cities were in the downwind of wildfires; typically winter concentrations dominated the annual means [3]. Particulate matter with diameters of $10 \mu \mathrm{m}$ or less $\left(\mathrm{PM}_{10}\right)$ had long-term mean concentrations of $12.4 \mu \mathrm{g} \cdot \mathrm{m}^{-3}$ in Fairbanks [3].

Residents of Interior Alaska experience extended episodes of wildfire-caused smoke in summer [3] [4] [5] [6]. The Interior encompasses two major river valleys, the Yukon Flats with the Yukon and Porcupine, and the Tanana Valley with the Tanana and its contributors (Figure 1). Over long periods of the year, the

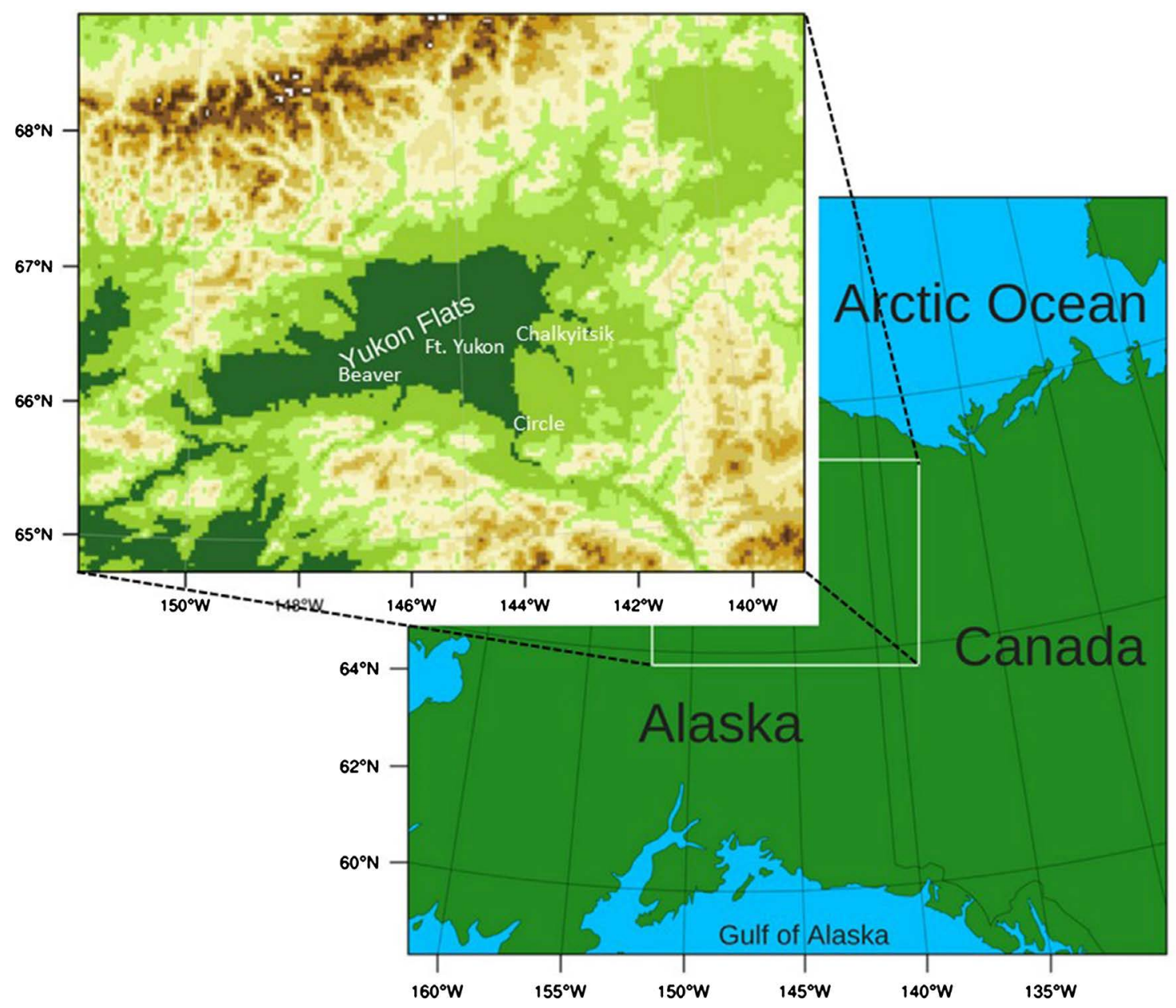

Figure 1. Schematic view of the location of the Yukon Flats in Alaska; topography and location of the four villages with sites of the tribal air quality network. 
topography drives the surface meteorology [7]. The location at the western edge of the Canadian High means frequent subsidence inversions. The far north location favors radiative cooling and inversion formation [8] [9] [10] [11]. Under both conditions, pollutants from local emissions can accumulate under the inversion over extended time yielding low air quality [10] [11]. The surrounding mountains retain the pollutants in the valley.

The concentrations that establish in response to emissions also depend on meteorological effects (e.g. mixing, transport, removal by sedimentation and washout, stability, inversion height if present), and natural sources of aerosols (e.g. mineral soils, pollen, gas-to-particle conversion, evaporation of hydrometeors, haze, cloud and fog droplets) [12] [13] [14].

Wildfires are a mechanism of the landscape evolution in Interior Alaska. Air-quality model simulations performed for the 2009 Minto Flats South wildfire in the Tanana Valley and the Crazy Mountain fire in the Yukon Flats showed that locally concentrations of near-surface $\mathrm{PM}_{2.5}$ exceeded the US National Ambient Air Quality Standard (NAAQS) of $35 \mu \mathrm{g} \cdot \mathrm{m}^{-3}$ [15] [16] notably over several days.

Air-quality model simulations and observations during the winter 2008/09 field campaign in Fairbanks, the largest city in Interior Alaska and the Tanana Valley showed local exceedances of the NAAQS over several days and on a regular basis between October and March on days with inversions [17]. In Fairbanks, emissions from wood burning contributed the majority of the $\mathrm{PM}_{2.5}$ in winter.

In the Yukon Flats, the largest valley in Alaska, most villages use local wood as the major source for heating and cooking, as any supply has to be flown in with small aircrafts [7]. In the Interior, $\mathrm{PM}_{2.5}$ concentrations $\left(\left[\mathrm{PM}_{2.5}\right]\right)$ often exceeded the NAAQS at the sites at Gates of the Arctic (located west of the Yukon Flats), in the cities of Fairbanks and North Pole (Tanana Flats), and Denali National Park Head Quarters (southern Interior) in summer due to smoke from wildfires [3].

Nevertheless, and despite wildfires are part of the natural landscape evolution of the boreal forest ecosystem, aerosol near-surface data are sparse in the Tanana Valley and were even nonexistent in the Yukon Flats. In the sparsely populated Yukon Flats, most communities are off the Alaska road network [7]. Thus, maintenance of an air-quality monitoring network by federal or state agencies would require travel by boat or small aircrafts. Under limited funding conditions, such high maintenance costs for closing the data gap is hard to justify under the argumentation of cost-benefit ratio aspects.

Various studies linked high concentrations of $\mathrm{PM}_{2.5}$ from wildfires and wood burning to respiratory and cardiac illnesses especially in sensitive people with preconditions, children, and elderly [18] [19] [20]. In the rural Interior, medical emergencies often require air travel by charter for medical care [7], which contributes to elevated health care costs for rural villages.

Baselines of aerosol and meteorological surface data are vital for mitigation of 
air pollution, and any cost-efficient implementation of emission-control measures, policies, and intelligent decision-making processes. Such baselines can help identify sources, and direct the search for emission-control measures to mitigate health adverse air quality.

Recognizing the critical need of a baseline for improvement of human health, quality of life, conservation of prosperity, and ecosystem preservation in a rapidly changing world, the Tribes in the Yukon Flats decided to step up to fill a gap in atmospheric near-surface data on their own to assess the quality of the air they are breathing. A system of aerosol monitors and meteorological ground stations was placed in four Yukon Flats communities (Figure 1), and is managed by the Tribes of Ts'aahudaaneekk'onh Denh (Beaver), Gwichyaa Zheh (Fort Yukon), Jałgiitsik (Chalkyitsik), and Danzhit Khànląii (Circle). The objective was to establish a baseline inventory of air quality in the communities and to gain understanding of the sources of $\mathrm{PM}_{2.5}$ within these Interior Alaska villages.

\section{Experimental Design and Methodology}

\subsection{Network Layout and Site Descriptions}

Four Tribal villages were selected strategically to assess the summer air-quality situation in the Yukon Flats (Figure 1). Two villages (Circle, Chalkyitsik) are located close to the major river inlets into the valley at the Porcupine and Yukon River, respectively, one village (Beaver) is close to the outlet of the Yukon between the mountain ranges of the Yukon Flats, and a fourth village (Fort Yukon) is located at the Yukon in the center of the valley.

All communities follow a strong subsistence lifestyle. Except Circle, the communities are north of the Arctic Circle (66.56311N) (cf. Figure 1). Wood-stoves are the major choice for heating followed by diesel furnaces-some with modern monitors. The air quality monitoring sites were set up close to the major anthropogenic emission sources in these villages (Figure 2).

Circle (40 households, 104 inhabitants; $65.825 \mathrm{~N}, 144.0639 \mathrm{~W}, 179 \mathrm{~m}$ ) is the only village with access to the Alaska road network (Figure 2(a)). Its old part is along the upper end of the Yukon River's inlet from Canada into the Yukon Flats valley. Its new part is located three miles away from the old part of Circle. It is composed of residential private homes built along the Steese Highway, which is unpaved. The monitoring equipment is located in the center of the old village $(65.82569 \mathrm{~N}, 144.0639 \mathrm{~W})$ where all the permanent anthropogenic emission sources are located, such as the school, power plant, store, washiteria, and clinic (Figure 2(a)). The main, new airport is close to this part of Circle as well.

Chalkyitsik (24 households, 69 inhabitants, seasonally 35 households; $66.65222 \mathrm{~N}, 143.7258 \mathrm{~W}, 160.5 \mathrm{~m}$ ) was built along the Draanjik River (formally Black River). The center and oldest houses are along the banks of the Draanjik, newer residences are atop a hill on the other side of the airport (Figure 2(b)). In the center, all the permanent anthropogenic emission sources are located, such as the Council Office, washiteria, clinic, and heavy equipment (Figure 2(b)). The 


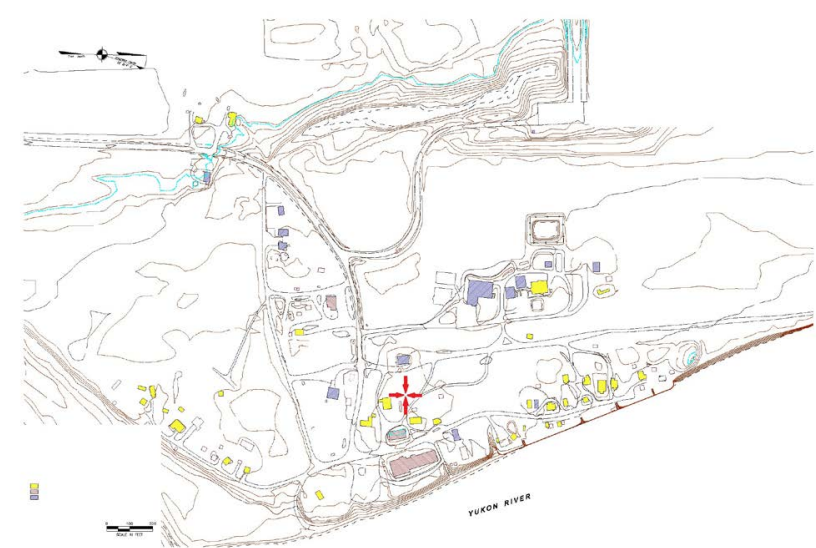

(a)

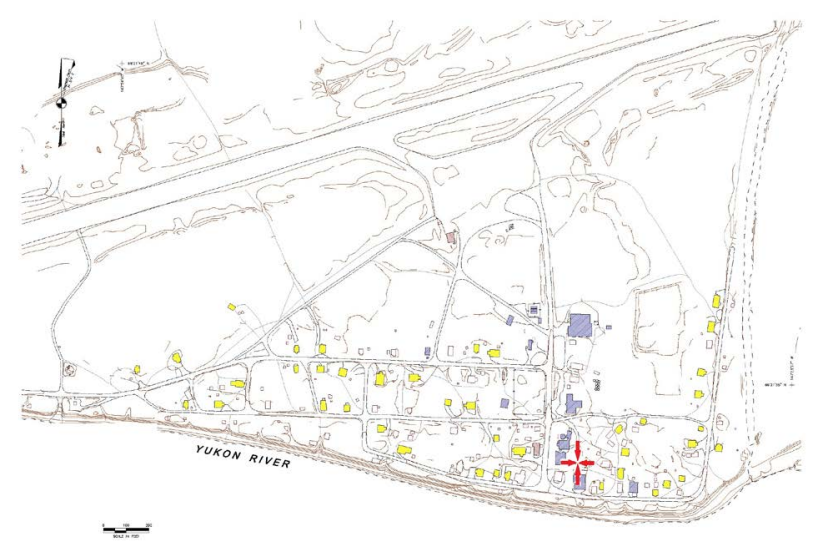

(c)

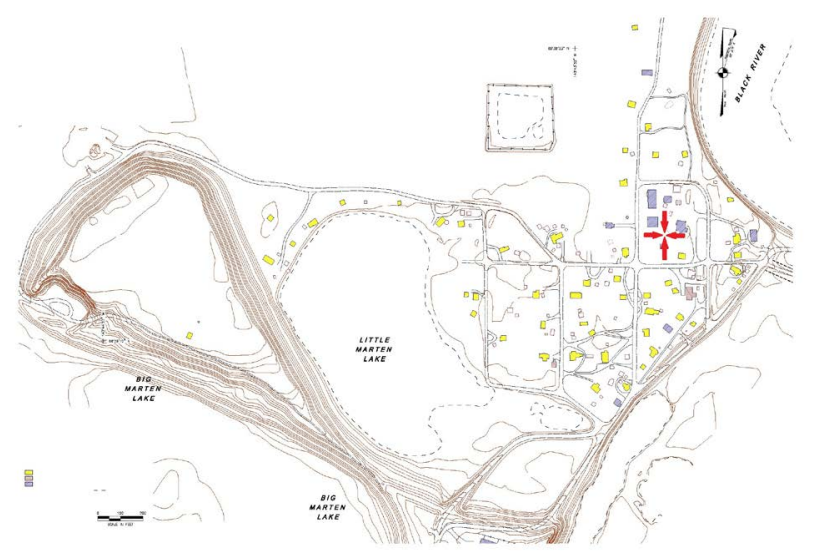

(b)

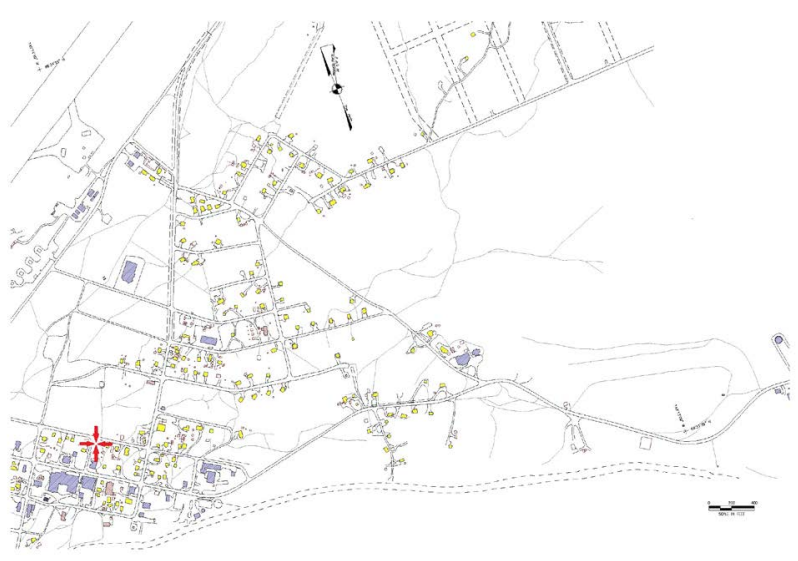

(d)

Figure 2. Maps of (a) Circle, (b) Chalkyitsik, (c) Beaver, and (d) Fort Yukon. The red cross marks the monitoring site location. Gray buildings are public buildings like school, power plant, council buildings, etc., yellow buildings are residencies. Brown lines are topography. Gray solid and dashed lines are streets and waters (rivers, lakes). Cyan represents rivers and lakes in (a).

monitoring site is located in the center of the village $(66.65413 \mathrm{~N}, 143.7229 \mathrm{~W})$. The school and power plant are on the hill.

Beaver (36 households, 84 inhabitants; $66.35972 \mathrm{~N}, 147.3975 \mathrm{~W}, 111 \mathrm{~m}$ ) is located along the northern banks of the Yukon River. Multiple roads exist parallel to the river bank with the oldest homes along the bank. The school, power plant, Tribal Council Offices, washiteria, clinic, and heavy equipment are in the village center. The monitoring site $(66.65413 \mathrm{~N}, 143.7229 \mathrm{~W})$ was set up behind the Council Office to capture pollution from the major, permanent anthropogenic emission sources (Figure $2(\mathrm{c})$ ). The school is further away from the river bank and about $100 \mathrm{~m}$ away from the site. The airport is behind the village (Figure 2(d)).

Fort Yukon (246 households, 583 inhabitants; 66.56667N, 145.2581W, $134 \mathrm{~m}$ ) was stablished in 1847 as a Hudson Bay Trading Post at the formerly seasonal gathering place Gwichyaa Zheh of the Gwichin people. It is one of oldest communities and the largest Athabascan community in Alaska. In summer, the population increases due to fire-fighter stationed there and tourists. Fort Yukon is located on the north bank of the Yukon River. In contrast to the other commun- 
ities, it has a piped water and sewer system. In the center of Fort Yukon, where the site was set up, there are stores, a post office, school, church, community center, radio station, biomass power plant, and the regional health clinic (Figure 2(d)). The airport is west of the monitoring site. During the fire season, the airport serves large retardant cargo carriers for landing and takeoff.

\subsection{Instrumentation}

The equipment used was the Met One Instruments' BAM-1022, and Decagon's EM50. This choice was based on cost, EPA-suggested equivalent method, minimal required maintenance, and standalone continuous monitoring with data storage. At each site, a $10 \mathrm{~m}$ mast was assembled with three anchoring points of three cables at $10 \mathrm{~m}$ and $5 \mathrm{~m}$ height each, anchored at 120 degree separation (Figure 3), and $4.88 \mathrm{~m}$ distance at three points. Decagon EM50 meteorological monitors were used to measure temperature, pressure, and relative humidity at $10 \mathrm{~m}$ height. At $2 \mathrm{~m}$, a 597 ambient temperature/barometric pressure/relative humidity combination sensor was used. Wind speed and direction were measured at $10 \mathrm{~m}$ height. At $5 \mathrm{~m}$ height, precipitation and total incoming radiation were observed. Met One Instruments BAM 1022 PM mass concentration monitors served to measure $\mathrm{PM}_{2.5}$ concentrations. The real-time time measurement interval was set to 5 minutes for all devices.

Each BAM-1022 was housed in a box to protect the air intake vents of the pumps from horizontally blown snow and dust, and solar radiation. The air intake tube reached out of the box's top to $2 \mathrm{~m}$ height. Air was drawn through a particulate size-selective inlet allowing only particulate matter of $10 \mu \mathrm{m}$ in diameter or less to pass. The air flow then entered a BGI VSCC Very Sharp Cut Cyclone (BX-808) particle size separator that permitted only $\mathrm{PM}_{2.5}$ or less to
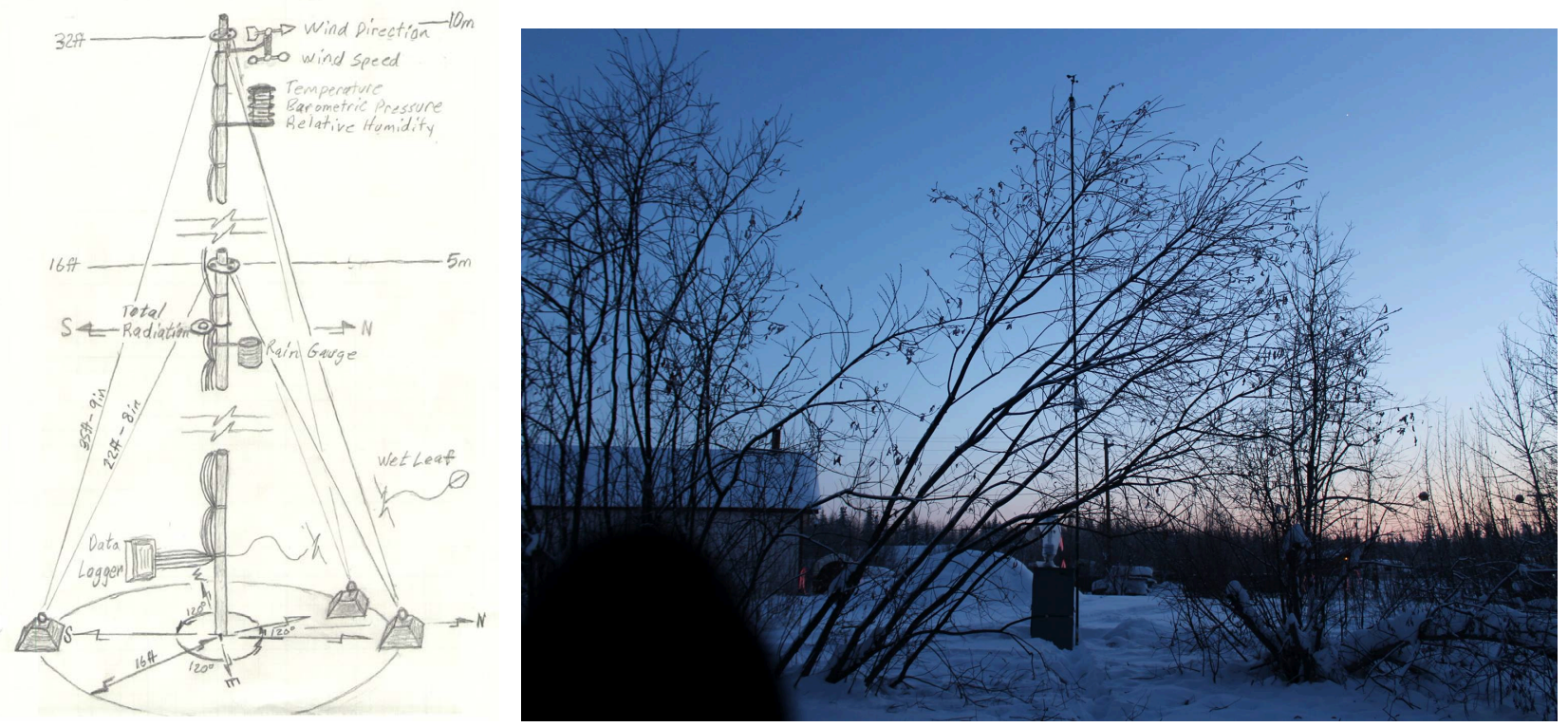

Figure 3. Pencil sketch of the mast and locations of its equipment (left) and photo of the monitoring equipment at Circle. The same equipment is used in all four tribal rural villages. 
pass. Table 1 lists the instruments' specifics.

In 2017, measurements were made from April 13 to August 19 at Circle, July 11 to September 17 at Beaver, and May 16 to November 13 at Ft. Yukon. At Chalkyitsik, observations were made from April 27, 2017 to February 10, 2018. For this study, we only used data from April to September to cover the wildfire season between breakup and freeze-up.

\subsection{Quality Assurance/Quality Control and Data Processing}

The data of BAM 1022 and the EM50 raw data were saved as two separate excel files. These data files were synchronized for time and combined. A quality assurance/quality control (QA/QC) protocol was run. Missing data were tagged as such. Data indicated as false by the instrument and/or values beyond the instrument's range were discarded and tagged as such. Only data with a common time tag were retained.

For all quantities, hourly, daily and monthly means and standard deviations were calculated. Daily means were compared with the $24-\mathrm{h}$ average of $35 \mu \mathrm{g} \cdot \mathrm{m}^{-3}$ recommended by the US Environmental Protection Agency (EPA) and the 3-day mean of $25 \mu \mathrm{g} \cdot \mathrm{m}^{-3}$ recommended by the World Health Organization (WHO) that should not be exceeded [21] [22]. The standard deviation is a good indicator of the concentration temporal variation over the day [23].

In addition, we calculated daily and monthly concentration means as a function of wind direction using the same algorithm as recommended by WHO and EPA [13] [21] [22]. Doing so permits assessment of contributing sources.

For better comparison of meteorological and concentration data we normalized these quantities as follows

$$
N_{\chi}=\frac{\chi}{\chi_{\max }-\chi_{\min }}
$$

Here the letter $\chi$ stands for the respective quantity, $\chi_{\max }$ and $\chi_{\min }$ are the maximum and minimum value observed in the timeframe under discussion. In case of concentrations and wind direction, $\chi_{\min }=0 \mu \mathrm{g} \cdot \mathrm{m}^{-3}$ and $\chi_{\max }=360^{\circ}$ and $\chi_{\min }=0^{\circ}$, respectively.

Table 1. Instrument characteristics. All data were sampled at a 5 minute rate.

\begin{tabular}{ccccc}
\hline \multirow{2}{*}{ Instrument } & \multicolumn{4}{c}{ Specifications } \\
\cline { 2 - 5 } & Observable & Range & Resolution & Accuracy \\
\hline \multirow{2}{*}{ Davis Cup Anemometer } & Wind direction & $>0^{\circ}$ to $360^{\circ}$ & $1^{\circ}$ & $\pm 7^{\circ}$ \\
& Wind speed & 0.9 to $78 \mathrm{~m} \cdot \mathrm{s}^{-1}$ & $0.04 \mathrm{~m} \cdot \mathrm{s}^{-1}$ & $\pm 5 \%$ \\
& Pressure & 500 to $1100 \mathrm{hPa}$ & $0.01 \mathrm{hPa}$ & $\pm 0.30 \mathrm{hPa}$ \\
VP-4 & Rel. humidity & 0 to $100 \%$ & $0.1 \%$ & $\pm 0.8 \%$ \\
& Air temperature & $-50^{\circ} \mathrm{C}$ to $70^{\circ} \mathrm{C}$ & $0.1^{\circ} \mathrm{C}$ & $\pm 0.1^{\circ} \mathrm{C}$ \\
BAM-1022 & $\mathrm{PM}_{2.5}$ & 0 to $10,000 \mu \mathrm{g} \cdot \mathrm{m}^{-3}$ & $0.1 \mu \mathrm{g} \cdot \mathrm{m}^{-3}$ & $\pm 0.1 \mu \mathrm{g} \cdot \mathrm{m}^{-3}$ \\
\hline
\end{tabular}




\section{Results and Discussion}

\subsection{Emissions Sources in the Yukon Flats}

Large emission sources with fixed locations are the power plant, laundry-mat, city office buildings, corporation buildings, businesses, school and support buildings, the Tribal Council and Tribal Consortium buildings; and if existent, the clinic. These sources burn grade- 1 diesel fuel for heating and power generation. Emissions depend on the time of day, day of the week, and time of the year as well as outside weather conditions.

Residential emissions stem from furnaces burning grade-1 diesel fuel and/or woodstoves for heating in winter; sporadic heating occurs in the other seasons. Burning patterns are dependent on the season. Most residents use a combination of both, when the woodstove goes out, the furnace kicks on, mostly during the nights. In contrast to Circle, Beaver and Chalkyitsik, spatial heating with diesel fuel dominates in the proximity to the monitor in Fort Yukon. In Fort Yukon, wood burning occurs only in the outskirts.

The season of the year and subsistence seasons lead to highly variable anthropogenic sources of aerosols and their precursors within a village and/or its surroundings.

Year round, residents burn wood outside to cook dog food using similar wood as for their woodstoves. The time of cooking is season dependent. In summer, cooking takes place in the mornings as cooling of the food takes longer than in winter. Low ambient temperatures shorten the cooling time, for which cooking occurs more towards the evening in winter. In the shoulder seasons (April, May, September, October), the time of cooking emissions varies strongest with some dependency on ambient temperature.

The type of wood burned and whether the fire is enclosed or open affect the amount of emissions. Fires in smoke drying caches burn rotten wood to produce smoke. Emissions from smoking vary depending on the subsistence availability of fish and moose during the hunting season. Moose meat drying and preservation through smoke caches occurs in fall in the villages, while fish drying occurs in summer dependent on availability. Drying can occur in the village or out along the river in fish camps.

In most villages, automobiles exist even though they lack access to the Alaska road network. Ft. Yukon and Circle have a large assortment of privately owned and municipal vehicles that are fueled with gas or diesel. Cold starts lead to enhanced emissions [24] as compared to summer. In the cold and transition seasons, idling of automobiles to warm up the engine also contribute to traffic emissions. Off-road vehicles are mostly four-wheelers and snow mobiles. Snow mobiles are used as long as snow is on the ground, while four-wheelers are used year-round.

The major transportation within Alaska is aircrafts and motorboats [7]. Aircrafts use leaded fuel due to the high octane requirement. Scheduled flights exist every day for Circle, Beaver, and Chalkyitsik. Ft. Yukon has multiple scheduled 
flights daily. Here, the number of starts/landings is highest in the summer during forest fire season, followed by fall due to the hunting season. Emissions from river traffic start after river breakup and are highest during the fall moose-hunting season. Other sources of aerosols are the village road systems and dust from river gravel bars [3].

As aforementioned, wildfires are a natural driver of the landscape evolution in the Yukon Flats. In 2017, seven major wildfires burned in the Yukon Flats. The Campbell River, Seven Mile, Boulder Creek, Bear Mountain, Deadman Island, Forty and One Half, and Chandelar fires started on June 26, June 29, July 2, July 9 , July 20 , July 21 , and July 24 , respectively. These fires were still active September 27, 2017. There also was a huge fire in Canada close to the border (Figure 4).

\subsection{Common Features}

At all four communities, $\left[\mathrm{PM}_{2.5}\right]$ showed the following behavior. Surface inversions occurred under calm wind conditions due to radiative cooling. Often more than one inversion formed per day (cf. Figure 5).

When smoke was transported at layers above the surface inversion, 2-m $\left[\mathrm{PM}_{2.5}\right]$ remained low, and was explainable by the local emissions; 24 -h means remained below the WHO recommendation. Such conditions occurred when the large-scale forcing was weak, i.e. near-surface winds were between 2 and $5 \mathrm{~m} \cdot \mathrm{s}^{-1}$. Under these conditions, the inversion protected the community from the smoke (Figure 6(a)). However, concurrently, all emissions below the inversion accumulated underneath the inversion with time. The smoke aloft reduced the incoming insolation and heating of the surface; absorption of solar radiation in the smoke layer and upward scattering may have contributed to the stability and fostered the persistence of the inversion.

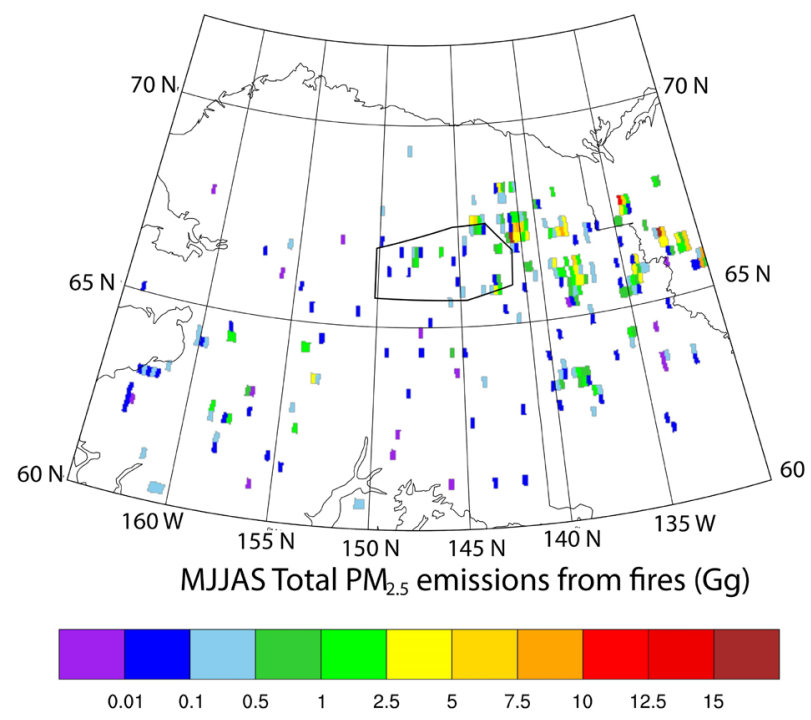

Figure 4. Emissions of $\mathrm{PM}_{2.5}$ from wildfires during May to September (MJJAS) 2017. The black polygon indicates the location of the Yukon Flats valley. Data from the Global Fires Emissions Database (GFED) version 4 [25]. 


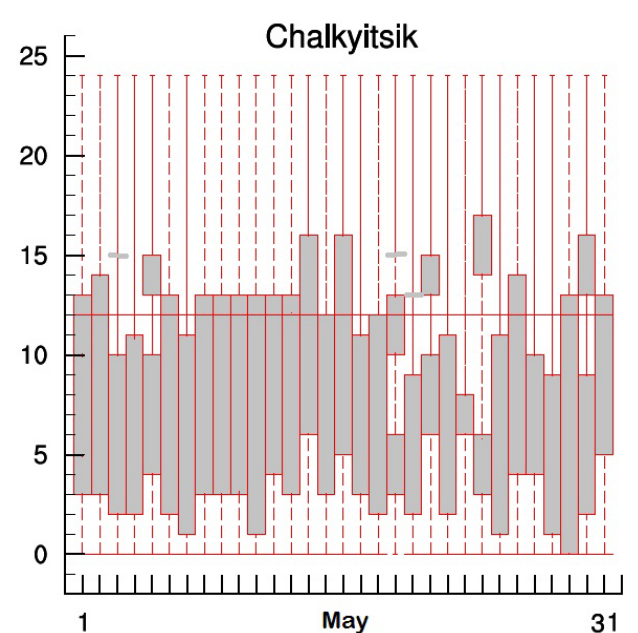

(a)

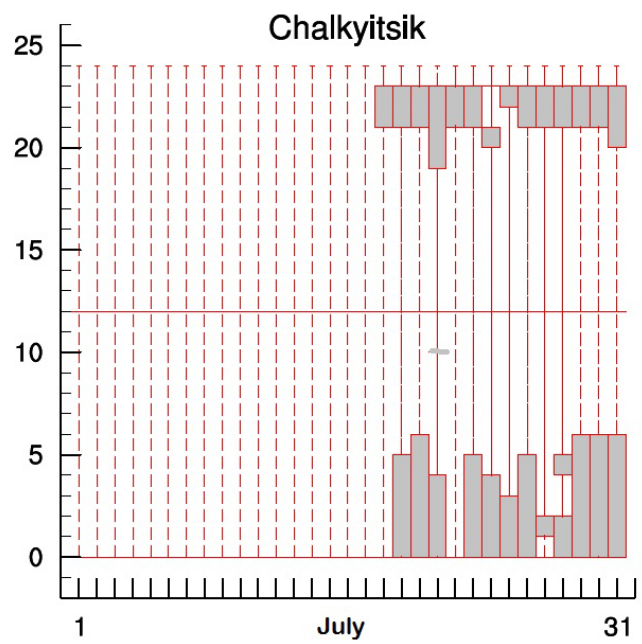

(c)

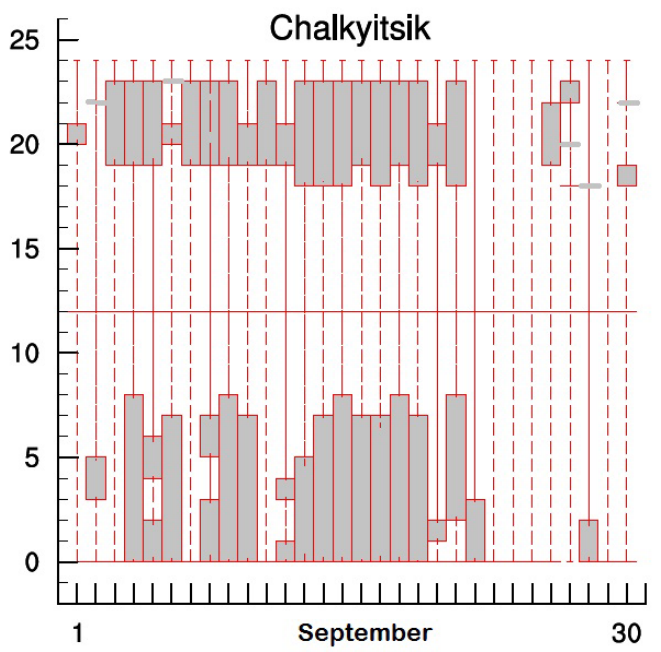

(e)

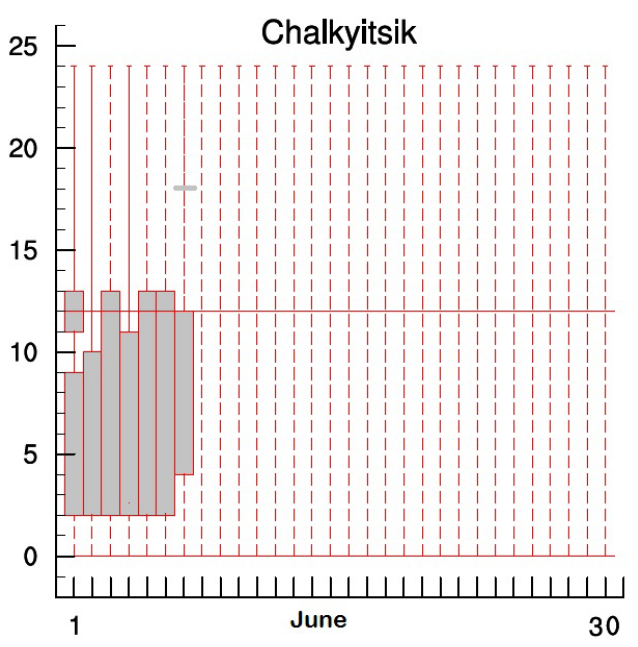

(b)

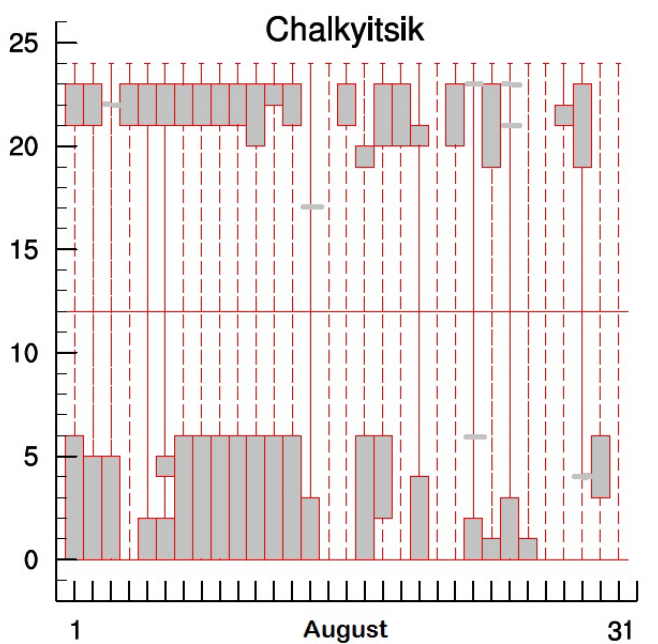

(d)

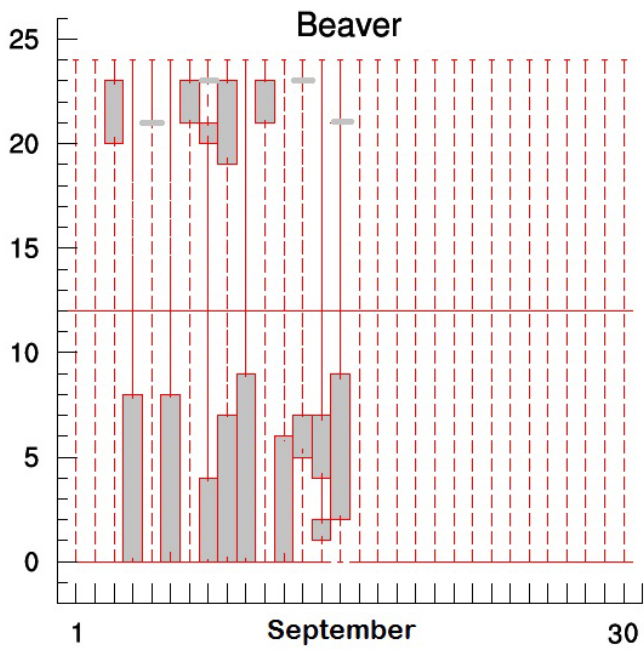

(f)

Figure 5. Temporal evolution of observed surface inversions and their durations (a)-(e) from May to September 2017 at Chalkyitsik, and (d) in September at Beaver. Plots for other communities look similar. Therefore not shown. 


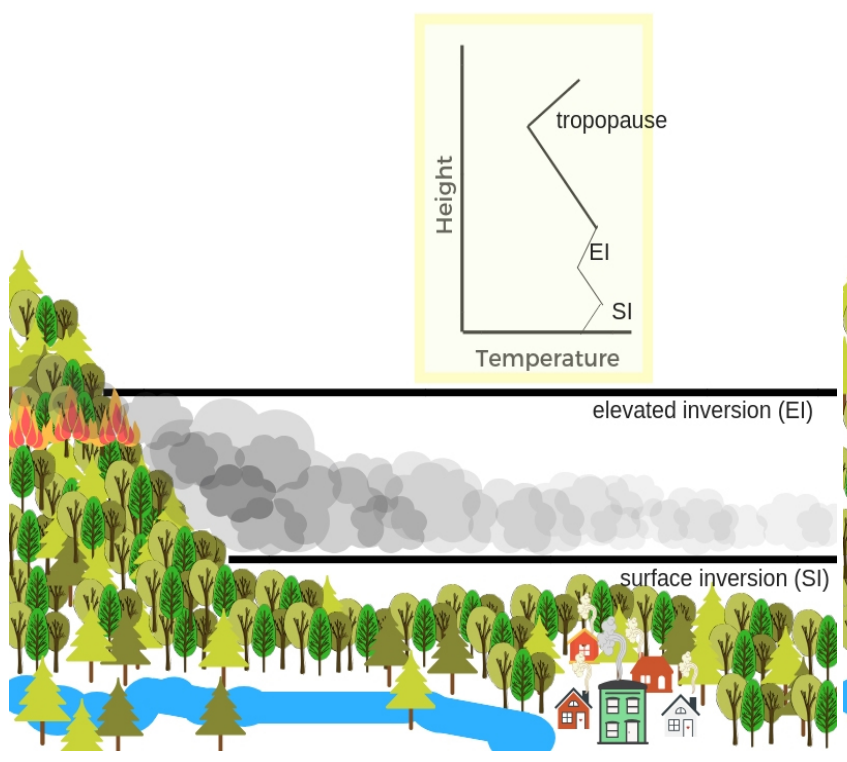

(a)

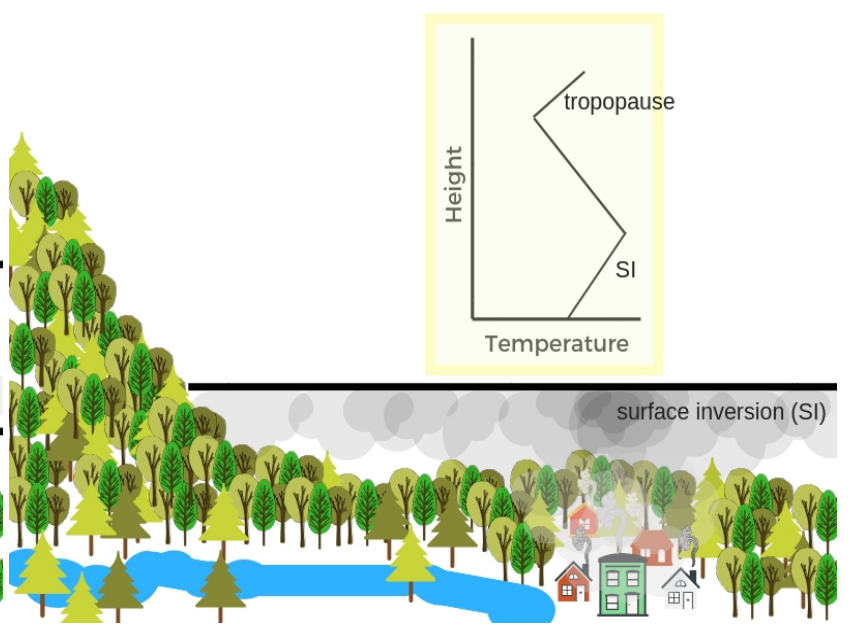

(b)

Figure 6. Schematic view of situations when the interaction of large-scale (calm wind, radiative cooling) and meso-scale (topography) forcing led to local inversions. (a) Inversion condition that may protect communities in the Yukon Flats from being affected by smoke from distant wildfires, and (b) inversion conditions that may cause accumulation of pollutants from local sources and, if applicable, advection from smoke that existed below the inversion (e.g., by channeling effects along a river between deep mountains).

When winds were calm $\left(<1 \mathrm{~m} \cdot \mathrm{s}^{-1}\right)$ surface heating led to convection and mixing. Under these condition, 24-h mean $\left[\mathrm{PM}_{2.5}\right]$ exceeded the WHO recommended threshold of $25 \mu \mathrm{g} \cdot \mathrm{m}^{-3}$, but remained far low unhealthy levels.

For all communities, daily mean concentrations exceeded the NAAQS on several days, often for several consecutive days, when smoke from wildfires was advected. Individual 5-minutes means as well as the values of temporal standard deviations were at levels considered as unhealthy.

When a cyclone governed the weather in the region, concentrations were lowest due to scavenging, washout and rainout. After the end of precipitation, typically concentrations built up to about the monthly baseline value in about one hour (e.g. Figure 7). In the following, the term "baseline value" refers to the mean concentration in a community averaged over all days without fire backward trajectory. An example of this type of concentration-precipitation behavior will be discussed in Section 3.5.

Another common feature was that under weak wind, high pollution situations precipitation only mitigated air quality during the event; concentrations went up immediately thereafter. This scenario occurred when communities where downwind of a fire. See Section 3.5 for an example.

A further common feature found for all villages was that the wind direction change associated with a frontal passage put a community immediately in the downwind of a fire. Then concentrations increased as soon as the rain stopped. Observed concentrations exceed the baseline value and those prior to the rain event (e.g. Figure 7(a)). For further discussion see Section 3.5. 

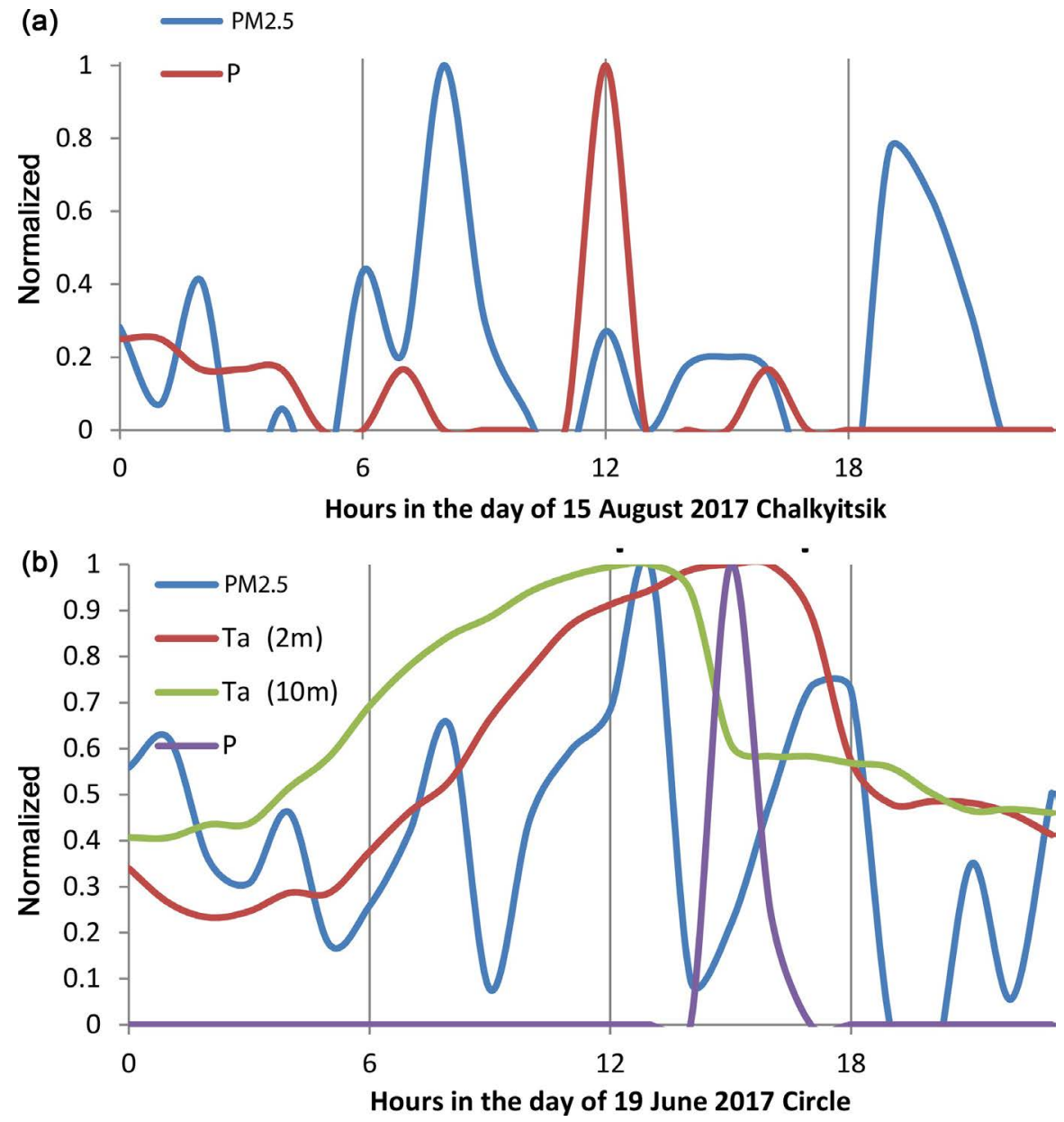

Figure 7. Normalized observed precipitation $(\mathrm{P})$ and $\left[\mathrm{PM}_{2.5}\right]$ to illustrate the impact of rain on pollutant concentrations. Examples shown are for (a) Chalkyitsik on August 15, 2017, and (b) Circle on June 19, 2017. Plots for other times and communities look similar when precipitation occurred under baseline or polluted conditions (therefore not shown).

\subsection{Circle}

Daily mean $\left[\mathrm{PM}_{2.5}\right]$ and their standard deviations remained typically below the $25 \mu \mathrm{g} \cdot \mathrm{m}^{-3}$ of the WHO-recommended 3-day mean except in July (Figure 8). A wildfire to the southeast (Figure 4) led to exceed the NAAQS 24-h average of 35 $\mu \mathrm{g} \cdot \mathrm{m}^{-3}$.

The high standard deviations reflect the high variability of pollutant concentrations on the short time scale. As soon as roads and riverbanks were snow-free and in June, July, August (JJA), on a 5 minute by 5 minute basis, $\left[\mathrm{PM}_{2.5}\right]$ exceeded $35 \mu \mathrm{g} \cdot \mathrm{m}^{-3}$ when wind came from the unpaved road or upper Yukon River (not shown). This value was also exceeded when the site was in the downwind of the school, generator plant, or washiteria, and during cooking time due to emissions from woodstoves in dog yards.

In July, a few peaks of daily mean $\left[\mathrm{PM}_{2.5}\right]$ occurred (Figure 8). But none of the data available were in a 3-day sequence. All the monthly mean $\left[\mathrm{PM}_{2.5}\right]$ remained below $25 \mu \mathrm{g} \cdot \mathrm{m}^{-3}$. The standard deviation indicated that there were a number of 


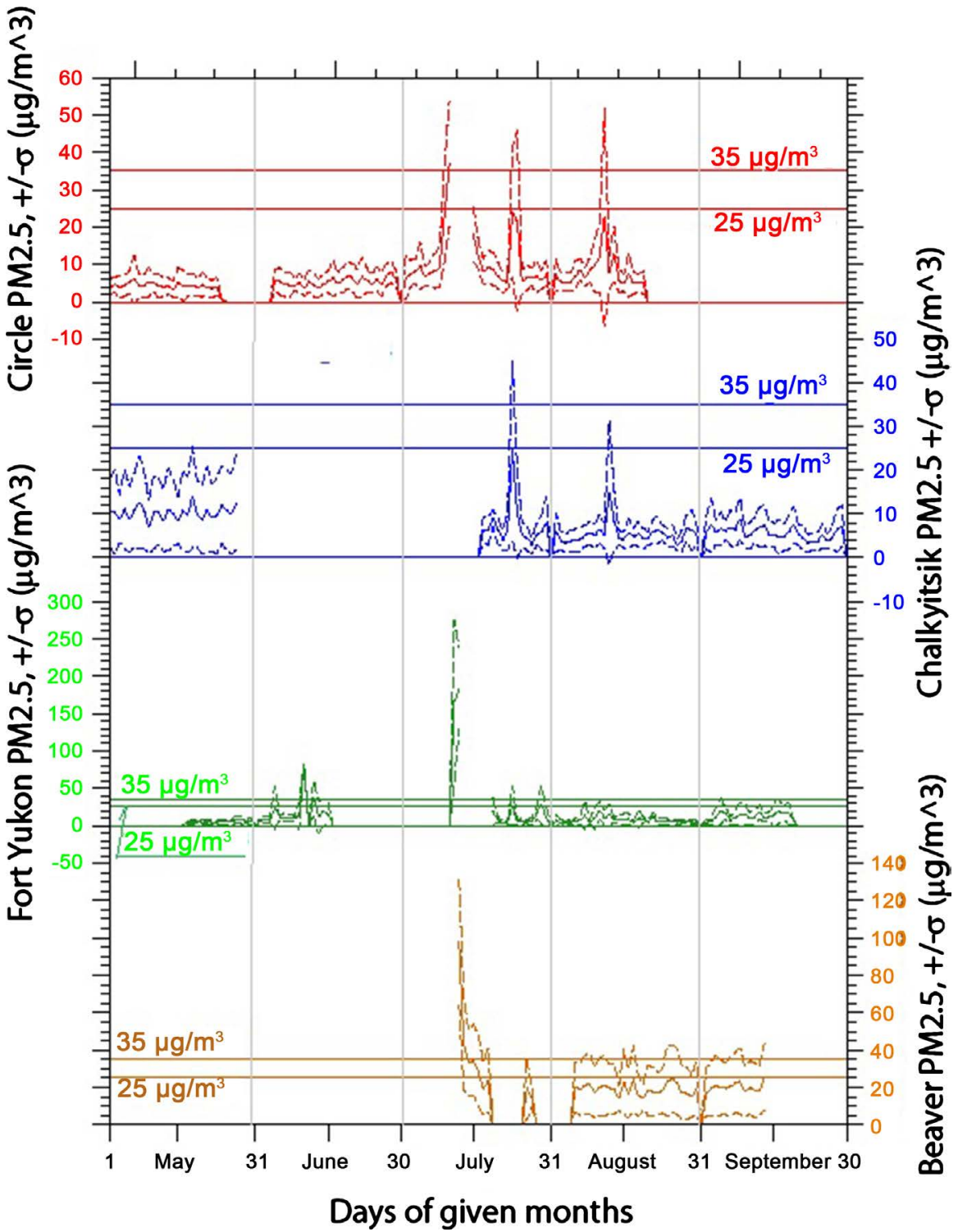

Figure 8. Temporal evolution of observed daily means of $\mathrm{PM}_{2.5}$ concentrations (solid lines) and standard deviations ( $\sigma$; dashed lines) at Circle (red), Chalkyitsik (blue), Ft. Yukon (green), and Beaver (brown) from May to September, 2017. The horizontal lines show the WHO and EPA recommended 24h-average not to be exceeded. The peaks on June 19, July 9, 20-21, and 24, August 12-15 at Circle, on August 13 and 15, at Chalkyitsik, May 20 at Ft. Yukon, August 23 and September 11 at Beaver are discussed in Sections 3.3 to 3.6 .

short-term peaks over times less than a day (Figure 8).

Eliminating all daily mean $\left[\mathrm{PM}_{2.5}\right]$ of days when Circle was in the downwind of a wildfire, suggests $2.0 \mu \mathrm{g} \cdot \mathrm{m}^{-3}, 3.8 \mu \mathrm{g} \cdot \mathrm{m}^{-3}, 8.6 \mu \mathrm{g} \cdot \mathrm{m}^{-3}$, and $6.2 \mu \mathrm{g} \cdot \mathrm{m}^{-3}$, as baseline values of the monthly means for May to August, respectively (Table 2). This means that wildfires contributed about $0 \mu \mathrm{g} \cdot \mathrm{m}^{-3}, 0.1 \mu \mathrm{g} \cdot \mathrm{m}^{-3}, 2.1 \mu \mathrm{g} \cdot \mathrm{m}^{-3}$, and 1.3 $\mu \mathrm{g} \cdot \mathrm{m}^{-3}$ to the observed monthly mean concentrations at Circle in 2017.

Figure 7 shows an event where the impact of a local emission source on the $\left[\mathrm{PM}_{2.5}\right]$ was observed. An inversion had trapped the local pollution. However, as 
Table 2. Monthly means of baseline $\mathrm{PM}_{2.5}$ concentration values averaged over all days without advection of smoke from wildfires, and in brackets monthly means averaged over all days with data. Note: -.- indicates no data available.

\begin{tabular}{ccccc}
\hline \multirow{2}{*}{ month } & \multicolumn{4}{c}{$\left[\mathrm{PM}_{2.5}\right]\left(\mu \mathrm{g} \cdot \mathrm{m}^{-3}\right)$} \\
\cline { 2 - 5 } & Beaver & Chalkyitsik & Circle & Ft. Yukon \\
\hline May &.$--(-.-)$ & $5.4(6.5)$ & $1.9(2.0)$ & $5.4(5.4)$ \\
June &.$--(-.-)$ &.$--(-.-)$ & $3.7(3.8)$ & $8.7(12.7)$ \\
July & $15.1(34.8)$ & $4.3(5.5)$ & $6.5(8.6)$ & $5.9(20.3)$ \\
August & $5.5(13.2)$ & $2.8(3.2)$ & $4.9(6.2)$ & $4.4(5.7)$ \\
September & $5.7(14.2)$ & $3.4(3.5)$ &.$--(-.-)$ & $7.2(11.1)$ \\
\hline
\end{tabular}

wind took up and it started to rain, the inversion dissipated. High $\left[\mathrm{PM}_{2.5}\right]$ were observed whenever the wind came from the immediate direction of a strong emission source located in Circle.

\subsection{Chalkyitsik}

In May to early June, daily mean $\left[\mathrm{PM}_{2.5}\right]$ boarder-lined $25 \mu \mathrm{g} \cdot \mathrm{m}^{-3}$ (Figure 8 ), but 5-minute average $\left[\mathrm{PM}_{2.5}\right]$ exceeded often $35 \mu \mathrm{g} \cdot \mathrm{m}^{-3}$ due to heavy equipment idling for warm-up. May monthly means were $6.5 \mu \mathrm{g} \cdot \mathrm{m}^{-3}$. In June, a wildfire burned in close proximity (cf. Figure 1, Figure 4), but the instrument had a failure. The limited July data indicated daily averages of nearly $50 \mu \mathrm{g} \cdot \mathrm{m}^{-3}$ (Figure 8), which is deemed unhealthy according to EPA standards [26]; 5-minute means reached up to $250 \mu \mathrm{g} \cdot \mathrm{m}^{-3}$ when winds came from the direction of the fire (Figure 9(a)). In the last third of July, daily means and variations of $\left[\mathrm{PM}_{2.5}\right]$ remained below $25 \mu \mathrm{g} \cdot \mathrm{m}^{-3}$ except for July 23 (Figure 8) when smoke was advected from the Little Black fire. In August and September, $\left[\mathrm{PM}_{2.5}\right]$ varied around the monthly means of 3.2 and $3.5 \mu \mathrm{g} \cdot \mathrm{m}^{-3}$, respectively except for around August 12 when smoke was advected from the Canadian Border fire (Figure 4). In September, temperatures started to go down for which heating with woodstoves set on. However, September 2017 was warmer than May 2017 for which September $\left[\mathrm{PM}_{2.5}\right]$ were lower (Table 2), but day-to-day variations looked similar to those in May (Figure 8). This means Chalkyitsik's local emissions caused a clearly identifiable pattern of $\left[\mathrm{PM}_{2.5}\right]$ which depended on wind direction, temperature and ground conditions (e.g. Figure 9).

Figure 9(a) exemplarily shows the response of $\left[\mathrm{PM}_{2.5}\right]$ to local emissions on August 13, 2017. The rain had little effect on the low $\left[\mathrm{PM}_{2.5}\right]$. This means these concentrations were the baseline values $\left[\mathrm{PM}_{2.5}\right]$ in the community. They broadly agree with the monthly mean determined for days without advection from wildfire smoke (Table 2). Early in the morning, a weak temperature inversion trapped emissions from the village and let to higher $\left[\mathrm{PM}_{2.5}\right]$ than the baseline values. The increase in $\left[\mathrm{PM}_{2.5}\right]$ in the early afternoon was due to dust uptake by wind, vertical mixing, and convection, but stemmed from sources within the village. The wind was blowing from the Porcupine inlet to the village. 


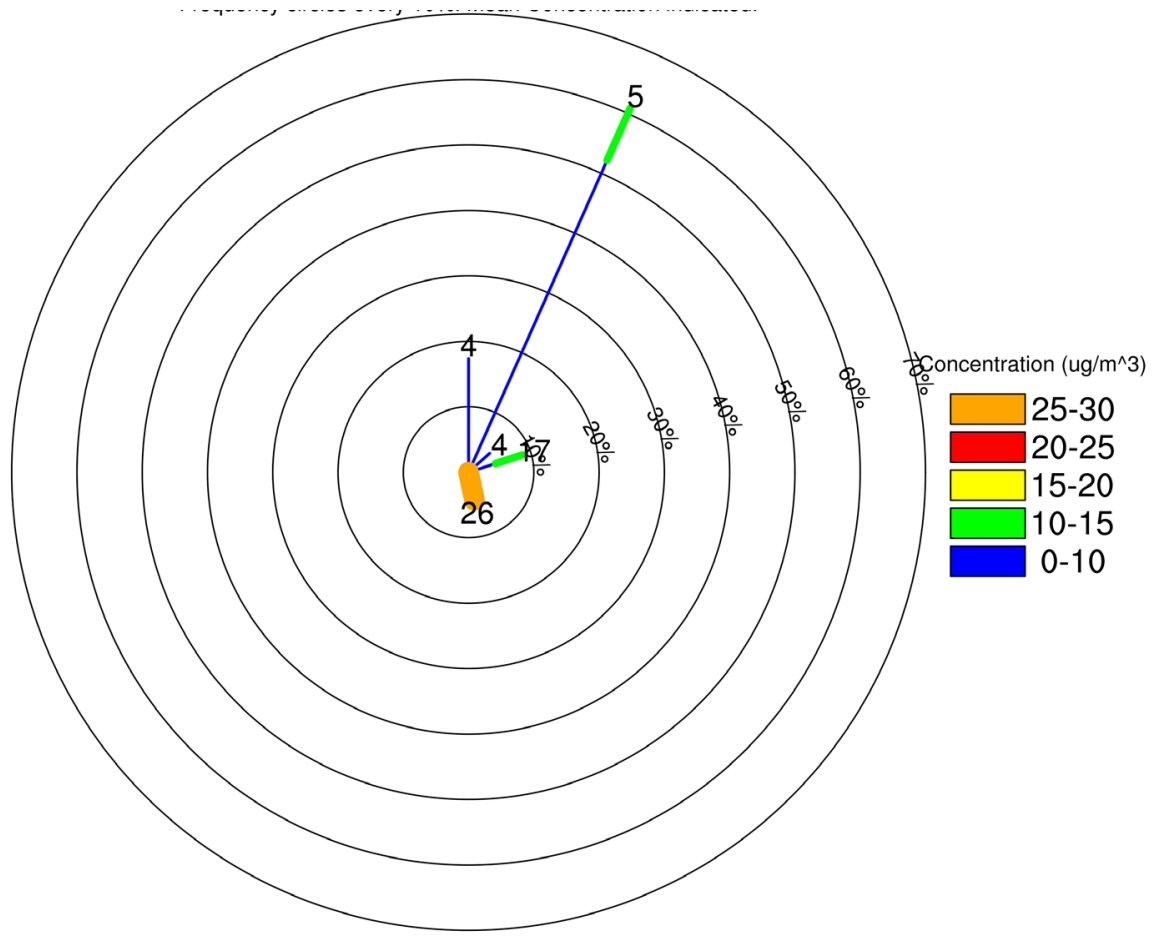

(a)

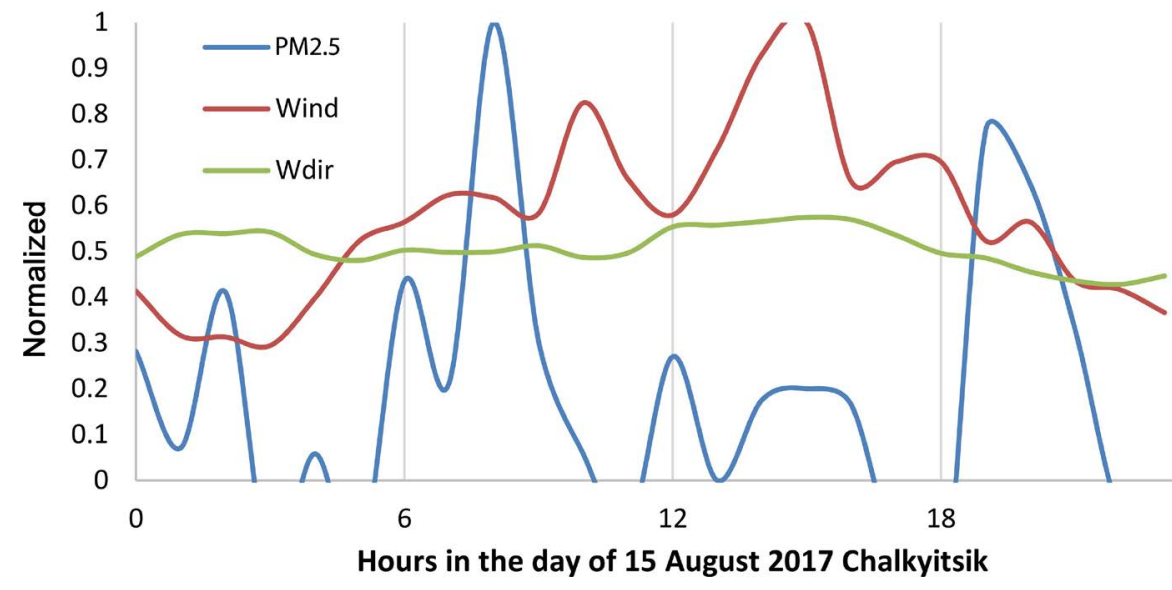

(b)

Figure 9. Examples of the pollution-meteorology relationships at Chalkyitsik. (a) Wind rose with frequency (circles) of occurrence (in percent) of an observed $\left[\mathrm{PM}_{2.5}\right]$ from the respective wind directions on August 13, 2017. The value at the end of the bar gives the mean averaged concentration over the time that wind came from the respective direction. The $24 \mathrm{~h}$-average was $8 \pm 8 \mu \mathrm{g} \cdot \mathrm{m}^{-3}$. No calm conditions occurred. (b) Normalized observed precipitation $\left[\mathrm{PM}_{2.5}\right]$ as a function of wind direction (Wdir) and wind speed (Wind) on August 15, 2017. See Figure 7(a) for the precipitation-pollutant relationship.

\subsection{Beaver}

In 2017, Beaver's air quality was influenced by a wildfire to the southwest in July, and by the Canadian Border fire to the north in September (cf. Figure 4). During July 24 -h average $\left[\mathrm{PM}_{2.5}\right]$ reached more than $100 \mu \mathrm{g} \cdot \mathrm{m}^{-3}$ and exceeded 35 $\mu \mathrm{g} \cdot \mathrm{m}^{-3}$ for an entire week (Figure 8). In August, $\left[\mathrm{PM}_{2.5}\right]$ exceeded $25 \mu \mathrm{g} \cdot \mathrm{m}^{-3}$ on all 
days, and $35 \mu \mathrm{g} \cdot \mathrm{m}^{-3}$ on 8 days. August 5 -minutes values reached up to $120 \mu \mathrm{g} \cdot \mathrm{m}^{-3}$. In the first half of September, 24-h means exceeded $35 \mu \mathrm{g} \cdot \mathrm{m}^{-3}$ on all days, and reached an unhealthy concentration of $80 \mu \mathrm{g} \cdot \mathrm{m}^{-3}$ on 9-14-2017; 5-minutes means reached up to $140 \mu \mathrm{g} \cdot \mathrm{m}^{-3}$.

The NAAQS was exceeded on six consecutive days in July (12-17), and on three consecutive days in August (15-17) as well as September (6-8) (Figure 8). In total, there were 18 days with $\left[\mathrm{PM}_{2.5}\right]$ exceeding $35 \mu \mathrm{g} \cdot \mathrm{m}^{-3}$. The July, August and September means averaged over all available data were $34.8 \mu \mathrm{g} \cdot \mathrm{m}^{-3}, 13.2$ $\mu \mathrm{g} \cdot \mathrm{m}^{-3}$, and $14.2 \mu \mathrm{g} \cdot \mathrm{m}^{-3}$, respectively (Table 2 ).

On days with wind blowing up or down the river, $\left[\mathrm{PM}_{2.5}\right]$ were elevated (36.9 $\pm 120 \mu \mathrm{g} \cdot \mathrm{m}^{-3}$ ). The lower Yukon River inlet into the Yukon Flats valley as seen from Beaver falls in the general direction of $225^{\circ} \pm 45^{\circ}$ from North (cf. Figure 1). The wind rose profile (e.g. Figure 10(a)) indicates that the largest wind and directional frequency and concentration values originated from and heading to this general direction towards and from the lower Yukon River inlet into the valley. The channeling effect pushed smoky air from fires in the west and east of Beaver up and down the river, respectively (cf. Figure 1, Figure 4, Figure 10(a)).

On days with calm winds, Beaver's location between relatively steep mountains to the East and West (Figure 1) favored the formation of inversions due to radiative cooling (Figure 5). The chimney of the power generation plant (Figure 2) typically reached above the inversion. The sandy river banks heated during the day. Occasionally, surface heating was sufficient enough to break the inversion (cf. Figure 5) allowing air from aloft to be mixed down. Then exhaust from the plant enhanced the $\left[\mathrm{PM}_{2.5}\right]$ (Figure 8, Figure 10(b)).

On days with relative high wind speeds $\left(\mathrm{v}>6 \mathrm{~m} \cdot \mathrm{s}^{-1}\right),\left[\mathrm{PM}_{2.5}\right]$ varied less than on calm days. On calm days without smoke advection, $\left[\mathrm{PM}_{2.5}\right]$ were low and depended on the wind direction and elevated concentrations were explainable by identified sources within the village. However, these concentrations remained below the WHO recommended value.

An example for the relation between pollution from distant sources and precipitation is August 28, 2017 (Figure 10(a)). On that day $\left[\mathrm{PM}_{2.5}\right]$ were low in Beaver in the morning and increased after the rain. Prior to the rain, wind was calm. No temperature inversion existed. At the onset of rain, wind speeded up and now came from the direction of the river. This means that the community was exposed to pollutants from its own emissions prior to the rain and later to smoke pollutants advected from outside.

The situation on September 11, 2017, is an example of build-up of $\left[\mathrm{PM}_{2.5}\right]$ in Beaver under a temperature inversion (Figure 10(b)). The rain caused the inversion to dissipate, and concentrations went down. They stayed low and there was some light wind. After sunrise, however, the ground started drying, and near-surface temperatures increased. A topography-driven local scale wind system established blowing from the cool river to the community. At the same time, concentrations increased due to advection of polluted air from outside the village. Note that wind from the river is the major wind direction at Beaver. 


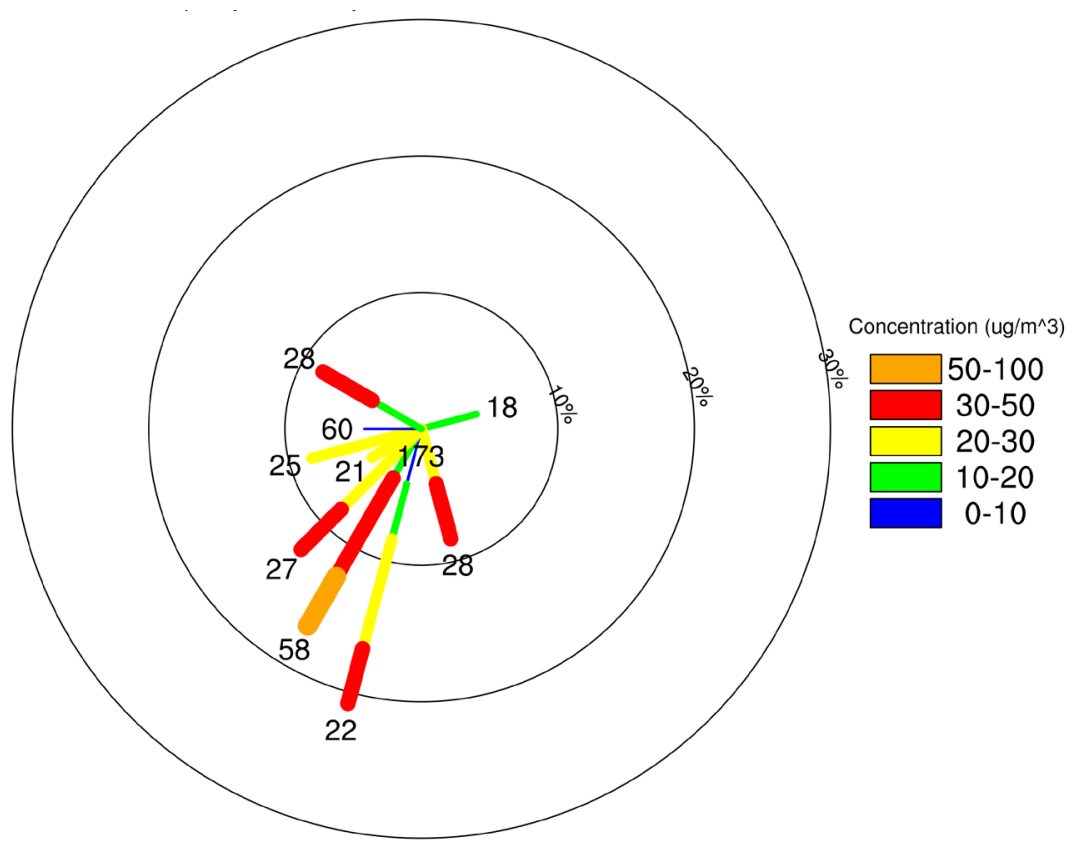

(a)

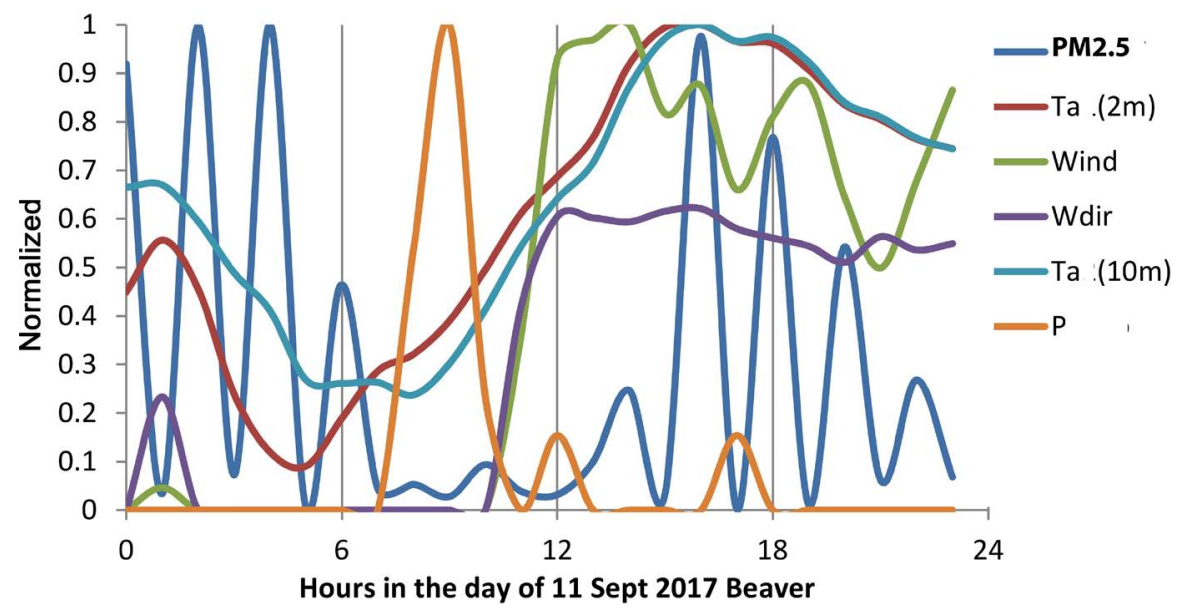

(b)

Figure 10. Examples of the pollution-meteorology relationships at Beaver. (a) Wind rose with frequency (circles) of occurrence (in percent) of an observed $\left[\mathrm{PM}_{2.5}\right]$ from the respective wind directions on August 28, 2017. The value at the end of the bar gives the mean averaged concentration over the time that wind came from the respective direction. The $24 \mathrm{~h}$-average was $41 \pm 42 \mu \mathrm{g} \cdot \mathrm{m}^{-3}$. No calm conditions occurred. (b) Normalized observed $\left[\mathrm{PM}_{2.5}\right]$ as a function of the temporal evolution of normalized wind direction (Wdir), wind speed (Wind), $2 \mathrm{~m}$ - and $10 \mathrm{~m}$-air temperature (Ta) and precipitation ( $\mathrm{P}$ ) on September 11, 2017.

August 12, 2017 is an example for a pollution-precipitation situation (Figure 8) where under weak wind, high concentration conditions, precipitation went up immediately after a precipitation event. Hourly mean $\left[\mathrm{PM}_{2.5}\right]$ of up to $45 \mu \mathrm{g} \cdot \mathrm{m}^{-3}$ decreased to $15 \mu \mathrm{g} \cdot \mathrm{m}^{-3}$ within $5 \mathrm{~min}$ after onset of precipitation. After the rain, $\left[\mathrm{PM}_{2.5}\right]$ went up to $30 \mu \mathrm{g} \cdot \mathrm{m}^{-3}$. This behavior was due to advection of polluted air from fires. 


\subsection{Fort Yukon}

Over the monitoring period, $\left[\mathrm{PM}_{2.5}\right]$ came from the city itself except for a week in July. Monthly mean concentrations were lowest in May $\left(5.4 \mu \mathrm{g} \cdot \mathrm{m}^{-3}\right)$ and increased over the summer and fall (June $12.7 \mu \mathrm{g} \cdot \mathrm{m}^{-3}$, July $20.3 \mu \mathrm{g} \cdot \mathrm{m}^{-3}$, August 5.7 $\mu \mathrm{g} \cdot \mathrm{m}^{-3}$, September $11.1 \mu \mathrm{g} \cdot \mathrm{m}^{-3}$; Table 2). This pattern is consistent with the use of diesel fuel for space heating and traffic. The temporal evolution of emissions is as follows. The monitors used for space heating led to reduced heating and hence decreasing emissions as outside warming progressed. In September, emissions increased as temperatures dropped. Traffic emissions increased in summer as more people were in town due to the tourist season and for accommodation of fire-fighters. Increased traveling on unpaved roads increased the amount of air-borne road dust, the availability of PM precursor gases, the amount of emitted primary PM and secondary PM from precursors. Frequent low-level inversions contributed to accumulation of $\left[\mathrm{PM}_{2.5}\right]$. As night-time temperatures went below freezing in fall, dust uptake by wind and traffic decreased due to frozen ground.

24-h means of $\left[\mathrm{PM}_{2.5}\right]$ exceeded $25 \mu \mathrm{g} \cdot \mathrm{m}^{-3}$ on eight days between late May and early November (Figure 8). Daily means reached more than $180 \mu \mathrm{g} \cdot \mathrm{m}^{-3}$ only in July when smoke was advected form a wildfire between Fort Yukon and Chalkyitsik (see Figure 4 for locations of fires). Such high concentrations are considered very unhealthy [26]. Note that 5-minutes means reached up to $300 \mu \mathrm{g} \cdot \mathrm{m}^{-3}$.

At Fort Yukon, the site was surrounded by buildings (school, court house, gym, AC store, radio station, post office, residences) to all sides (cf. Figure 2(d)). Thus, $\left[\mathrm{PM}_{2.5}\right]$ hardly differed by wind direction as long as no pollutants from fires were transported into the city. This means no matter whether there existed a temperature inversion or not, or whether wind was calm or not, concentrations were independent of wind direction when the pollutants were from local emissions within the city (Figure 11).

Under such conditions, the sources can be attributed. Under northwesterly, westerly to southwesterly emissions from the airport and downtown were major contributors. When winds came from southwest, south-south-west, south-south-east and southeast, emissions from the school, gym, radio station and AC stores contributed to the concentrations. While for winds from the southeast to northeast sector advected pollutants came from the uptown residences. Particles and dust from the road reached the site under north-north-east winds.

On June 1, 2017, for instance, pollutants at the site stemmed from the direction of the AC store, road, AC store, school, radio station, residences around 2, 3, 5, 6, 8 and 9 and later at $13 \mathrm{LT}$, respectively (cf. Figure 2(d), Figure 11(b), Figure 11(d)). On this day, an inversion built shortly after $1 \mathrm{LT}$ and broke after 16 LT (Figure 11(b)).

\subsection{Comparison with Fairbanks and Other Arctic Communities}

Fairbanks is the largest city in Interior Alaska and located in the Tanana Valley south of the Yukon Flats valley. Fairbanks' crow flight distance is about $223 \mathrm{~km}$, 


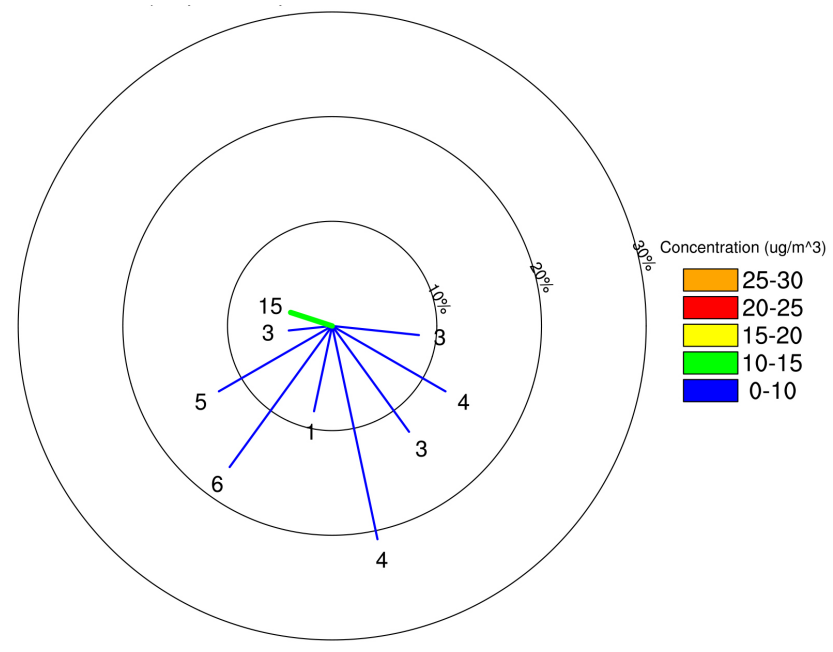

(a)

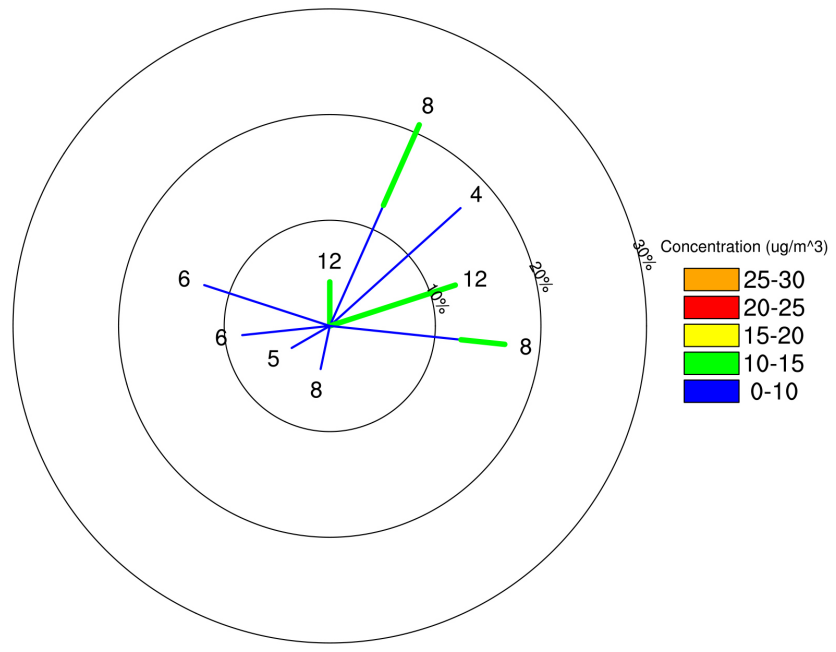

(b)

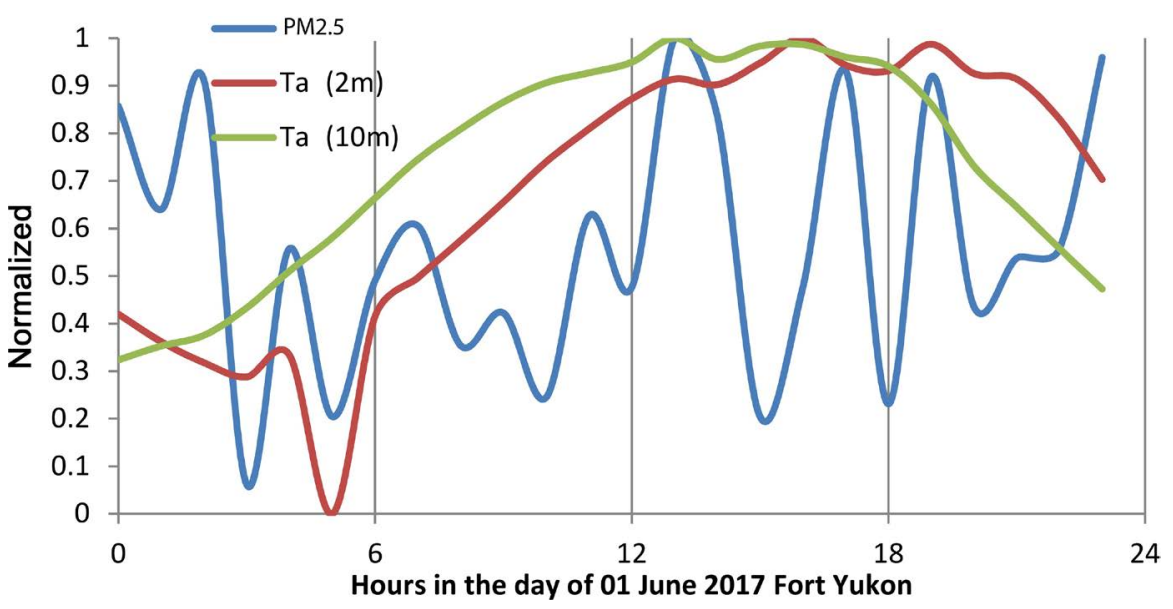

(c)

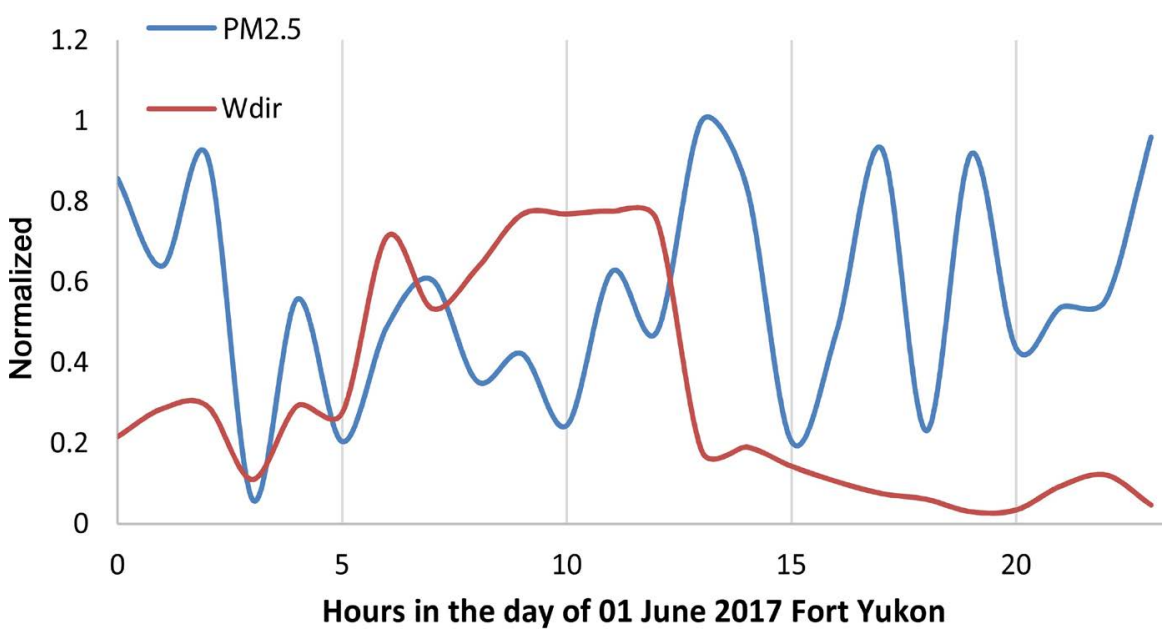

(d)

Figure 11. Hourly observed $\left[\mathrm{PM}_{2.5}\right]$ at Ft. Yukon and wind direction for (a) May 20, 2017, and (b) June 1, 2017. On both days, a nighttime inversion was present. Numbers on the circle and on the end of the bars indicate the frequency of occurrence of wind from that direction in percent, and the mean concentration under wind from that direction in $\mu \mathrm{g} \cdot \mathrm{m}^{-3}$. The colors indicate the concentration range as coded in the legends. The length of the colored bars give the frequency of occurrence of concentrations in the respective color coded concentration range. 
$170 \mathrm{~km}, 202 \mathrm{~km}$ and $272 \mathrm{~km}$ to Fort Yukon, Beaver, Circle and Chalkyitsik, respectively. Like the communities in the Yukon Flats, Fairbanks frequently experiences surface inversions [11] [27] [28] [29]. At the State Office Building in Fairbanks, 2017 June, July, August and September monthly means of daily 24-h $\left[\mathrm{PM}_{2.5}\right]$ were $5.3 \mu \mathrm{g} \cdot \mathrm{m}^{-3}, 6.3 \mu \mathrm{g} \cdot \mathrm{m}^{-3}, 2.6 \mu \mathrm{g} \cdot \mathrm{m}^{-3}$ and $2.8 \mu \mathrm{g} \cdot \mathrm{m}^{-3}$, respectively. These concentrations are substantially lower than those we found in the Yukon Flat communities (cf. Table 2). Note that in May 2017 only data were available for May $1\left(3.6 \mu \mathrm{g} \cdot \mathrm{m}^{-3}\right)$. The closer distance of the Yukon Flat communities to wildfires were a major reason. Other reasons are the farther North location and close distance to the semi-permanent Canadian High that increase the probability for inversions and hence accumulation of pollutants.

The Arctic 1972-2016 air-quality climatology of Arctic cities reported annual means of $24 \mathrm{~h}$ average $\left[\mathrm{PM}_{2.5}\right]$ of $3.6 \pm 11.9 \mu \mathrm{g} \cdot \mathrm{m}^{-3}$ and $4.6 \pm 27.5 \mu \mathrm{g} \cdot \mathrm{m}^{-3}$ for communities with less than 1000 inhabitants and similar Köppen-Geiger climate, respectively; the long-term Arctic background value (i.e. outside of communities) was $2.6 \pm 10.0 \mu \mathrm{g} \cdot \mathrm{m}^{-3}$ [3]. As compared to those data the communities in the Yukon Flats were exposed to substantially higher concentrations.

A major reason was the advection of smoke from wildfires within the Yukon Flats as well as those in the Yukon and Northwest Territories. Note these territories and Eastern Interior faced a record fire season in 2017. Due to the vast space of Interior Alaska, wildfires are only fought when they pose an immediate threat to human life, settlings and historic settings.

\section{Conclusions}

We established a Tribal owned meteorology and aerosol monitoring network to understand the exposure of eastern Interior Alaskan communities to the health-adverse $\mathrm{PM}_{2.5}$ from local and wildfire emissions. These sites were installed strategically in four communities of the Yukon Flats valley, two close to the two major inlets each, one close to the Yukon outlet and one in the middle of the valley. Measurements were made between May and September 2017 covering the time from breakup to the end of the Alaska fire season and onset of ambient air temperatures dropping below the freezing point.

As expected, the observations showed that radiative cooling under low surface wind speeds $\left(<1 \mathrm{~m} \cdot \mathrm{s}^{-1}\right)$ can lead to inversion formation and accumulation of local pollutants until winds or heating break the inversion and the pollutants are swapped out. Nevertheless, under these inversion conditions, daily mean $\mathrm{PM}_{2.5}$ concentrations remained below or around the $25 \mu \mathrm{g} \cdot \mathrm{m}^{-3}$ threshold that the WHO recommended not to be exceeded.

When communities were in the downwind of major wildfires, two different air quality situations occurred for all villages except Beaver.

1) If $2-\mathrm{m}$ wind speeds were between 2 and $5 \mathrm{~m} \cdot \mathrm{s}^{-1}$ in the presence of an inversion, the inversion may protect the communities from wildfire smoke advected towards them at levels above the inversion. Then communities only suffered 
from pollutants accumulated underneath the inversion that stemmed from local emissions. Under these conditions, daily mean $\mathrm{PM}_{2.5}$ concentrations remained below or around $25 \mu \mathrm{g} \cdot \mathrm{m}^{-3}$.

2) When convection existed or wind was too strong for the formation of an inversion, smoke was advected into the villages leading to daily mean concentrations that are deemed unhealthy according the EPA guidelines.

At Beaver in addition the following situation occurred. Smoke was captured underneath an inversion where the Yukon River had carved its way thru steep mountains near Beaver. Under these conditions, Beaver experienced advection of smoke within the surface inversion and hence elevated concentrations.

When a cyclone governed the weather in the Interior, concentrations were lowest due to scavenging, washout and rainout. After the end of precipitation, typically concentrations built up to about the monthly baseline in about one hour. Occasionally, the change in wind direction associated with a frontal passage advected smoke from upwind fires to the community.

When concentrations aloft were higher than in the village breaking of the inversion led to strong variations in concentrations due to the mixing processes of the two air masses of different degree of pollution.

Based on the results of this monitoring study we may conclude that between April and September, communities in the Yukon Flats breeze healthy air as long as their community is not impacted by smoke from upwind wildfires.

Under inversion conditions, communities could reduce their local emissions by plugging in heavy equipment and cars instead of idling them, or by keeping them in a hangar or garage when not in sue. Long-term goals to improve air quality under inversion conditions could be to opt for heating devices with the lowest emissions when old devices have to be replaced.

While communities have possibilities to mitigate local emissions, there are currently no measures at hand to mitigate the emissions from wildfires that cause the very unhealthy conditions for often more than a consecutive week several times during the wildfire season. Such measures would require to change the current wildfire management policy. Currently, only fires are fought that are an immediate threat for life, property, historic places and important infrastructure among other things.

Fighting all fires in the valley could reduce the exposure to wildfire smoke. Removal of dead or old trees and wood broken off by storm at a larger amount than just for local wood burning could reduce the available fuel for wildfires and the risk of lightning to ignite fires. The removed wood could be converted to pellets that burn more efficient and have lower emissions. Such a measure would require building a plant for the processing, roads to transport the wood to the plant and distribute it to the consumers, installations of pellet stoves and a much larger work force than it is currently available in the Yukon Flats. Although it is well-known that as population increases in boreal forest the number of human-caused fire increases.

However, changes in fire management are decisions made at the state level. 
Consequently, they would require political negotiations between local and state decision makers. Such negotiations can take years especially when the group of beneficiaries is comparatively small and the involved costs are extremely high. This fact is especially true under conditions of financial shortage. Nevertheless, even when the current fire management policy would be changed communities could still be exposed to smoke from atmospheric long-distance transport from boreal fires in Canada or even Siberia.

\section{Acknowledgements}

We thank the tribes of Beaver, Fort Yukon, Circle and Chalkyitsik for permitting to establish the sites and their support. We also thank them and the anonymous reviewers for fruitful discussion and helpful comments. We thank the Tribal Resilience Program for financial support of this study.

\section{Conflicts of Interest}

The authors declare no conflicts of interest regarding the publication of this paper.

\section{References}

[1] Western Regional Air Partnership (2007) Alaska Rural Communities Emission Inventory Report.

[2] Unites States Census Bureau (2015) National Population Projections. https://www.census.gov/population/projections/data/national/2014.html

[3] Mölders, N. and Kramm, G. (2018) Climatology of Air Quality in Arctic Cities-Inventory and Assessment. Open Journal of Air Pollution, 7, 48-93. https://doi.org/10.4236/ojap.2018.71004

[4] Mölders, N. and Kramm, G. (2007) Influence of Wildfire Induced Land-Cover Changes on Clouds and Precipitation in Interior Alaska-A Case Study. Atmospheric Research, 84, 142-168. https://doi.org/10.1016/j.atmosres.2006.06.004

[5] Grell, G.A., Freitas, S.R., Stuefer, M. and Fast, J.D. (2011) Inclusion of Biomass Burning in WRF-Chem: Impact on Wildfires on Weather Forecasts. Atmospheric Chemistry and Physics, 11, 5289-5303. https://doi.org/10.5194/acp-11-5289-2011

[6] Wendler, G., Conner, J., Moore, B., Shulski, M. and Stuefer, M. (2011) Climatology of Alaskan Wildfires with Special Emphasis on the Extreme Year of 2004. Theoretical and Applied Climatology, 104, 459-472. https://doi.org/10.1007/s00704-010-0357-9

[7] Edwin, S.G., Mölders, N., Friedrich, K., Schmidt, S. and Thoman, R. (2017) Conditions Supporting Funnel Cloud Development in Alaska. Atmospheric and Climate Sciences, 7, 223-245. https://doi.org/10.4236/acs.2017.72016

[8] Bourne, S.M., Bhatt, U.S., Zhang, J. and Thoman, R. (2010) Surface-Based Temperature Inversions in Alaska from a Climate Perspective. Atmospheric Research, 95, 353-366. https://doi.org/10.1016/j.atmosres.2009.09.013

[9] Devasthale, D., Willen, U., Karlsson, K.-G. and Jones, C.G. (2010) Quantifying the Clear-Sky Temperature Inversion Frequency and Strength over the Arctic Ocean During Summer and Winter Seasons from AIRS Profiles. Atmospheric Chemistry and Physics, 10, 5565-5572. https://doi.org/10.5194/acp-10-5565-2010 
[10] Mölders, N. and Kramm, G. (2010) A Case Study on Wintertime Inversions in Interior Alaska with WRF. Atmospheric Research, 95, 314-332. https://doi.org/10.1016/j.atmosres.2009.06.002

[11] Tran, H.N.Q. and Mölders, N. (2011) Investigations on Meteorological Conditions for Elevated $\mathrm{PM}_{2.5}$ in Fairbanks, Alaska. Atmospheric Research, 99, 39-49. https://doi.org/10.1016/j.atmosres.2010.08.028

[12] Seinfeld, J.H. and Pandis, S.N. (1997) Atmospheric Chemistry and Physics: From Air Pollution to Climate Change. John Wiley \& Sons, New York.

[13] Environmental Protection Agency (2007) Guidance on the Use of Models and Other Analyses for Demonstrating Attainment of Air Quality Goals for Ozone, $\mathrm{PM}_{2.5}$, and Regional Haze. 262.

[14] Mölders, N. and Kramm, G. (2014) Lectures in Meteorology. Springer, Heidelberg, 591. https://doi.org/10.1007/978-3-319-02144-7

[15] Madden, J.M., Mölders, N. and Sassen, K. (2015) Assessment of WRF/Chem Simulated Vertical Distributions of Particulate Matter from the 2009 Minto Flats South Wildfire in Interior Alaska by CALIPSO Total Backscatter and Depolarization Measurements. Open Journal of Air Pollution, 4, 119-138. https://doi.org/10.4236/ojap.2015.43012

[16] Mölders, N., Butwin, M., Madden, J., Tran, H., Sassen, K. and Kramm, G. (2015) Theoretical Investigations on Mapping Mean Distributions of Particulate Matter, Inert, Reactive, and Secondary Pollutants from Wildfires by Unmanned Air Vehicles (UAVs). Open Journal of Air Pollution, 4, 149-174. https://doi.org/10.4236/ojap.2015.43014

[17] Mölders, N., Tran, H.N.Q., Cahill, C.F., Leelasakultum, K. and Tran, T.T. (2012) Assessment of WRF/Chem $\mathrm{PM}_{2.5}$ Forecasts Using Mobile and Fixed Location Data from the Fairbanks, Alaska Winter 2008/09 Field Campaign. Air Pollution Research, 3, 180-191. https://doi.org/10.5094/APR.2012.018

[18] Moore, D., Copes, R., Fisk, R., Joy, R., Chan, K. and Brauer, M. (2006) Population Health Effects of Air Quality Changes Due to Forest Fires in British Columbia in 2003: Estimates from Physician-Visit Billing Data. Canadian Journal of Public Health, 97, 105-108.

[19] Liu, J.C., Pereira, G., Uhl, S.A., Bravo, M.A. and Bell, M.L. (2015) A Systematic Review of the Physical Health Impacts from Non-Occupational Exposure to Wildfire Smoke. Environmental Research, 136, 120-132. https://doi.org/10.1016/j.envres.2014.10.015

[20] Strickland, M.J., Hao, H., Hu, X., Chang, H.H., Darrow, L.A. and Liu, Y. (2015) Pediatric Emergency Visits and Short-Term Changes in $\mathrm{PM}_{2.5}$ Concentrations in the U.S. State of Georgia. Environmental Health Perspectives, 124, 690-696.

[21] EPA (2011) National Ambient Air Quality Standards (NAAQS). http://www.epa.gov/air/criteria.html

[22] World Health Organization (1999) Air Quality Guidelines. https://www.who.int/airpollution/en/

[23] Kim, J., Waliser, D.E., Mattmann, C.A., Mearns, L.O., Goodale, C.E., Hart, A.F., et al. (2013) Evaluation of the Surface Climatology over the Conterminous United States in the North American Regional Climate Change Assessment Program Hindcast Experiment Using a Regional Climate Model Evaluation System. Journal of Climate, 26, 5698-5715. https://doi.org/10.1175/JCLI-D-12-00452.1

[24] Weilenmann, M., Favez, J.-Y. and Alvarez, R. (2009) Cold-Start Emissions of Modern Passenger Cars at Different Low Ambient Temperatures and Their Evolution 
over Vehicle Legislation Categories. Atmospheric Environment, 43, 2419-2429. https://doi.org/10.1016/j.atmosenv.2009.02.005

[25] Randerson, J.T., van der Werf, G.R., Giglio, L., Collatz, G.J. and Kasibhatla, P.S. (2018) Global Fire Emissions Database, Version 4.1 (GFEDv4). ORNL DAAC, Oak Ridge.

[26] Environmental Protection Agency (2012) The National Ambient Air Quality Standards for Particle Pollution.

https://www.epa.gov/sites/production/files/2016-04/documents/2012_aqi_factsheet. pdf

[27] Wendler, G. and Nicpon, P. (1975) Low-Level Temperature Inversion in Fairbanks, Central Alaska. Monthly Weather Review, 103, 34-44.

https://doi.org/10.1175/1520-0493(1975)103<0034:LLTIIF>2.0.CO;2

[28] Mölders, N., Tran, H.N.Q., Quinn, P., Sassen, K., Shaw, G.E. and Kramm, G. (2011) Assessment of WRF/Chem to Capture Sub-Arctic Boundary Layer Characteristics During Low Solar Irradiation Using Radiosonde, Sodar, and Station Data. Atmospheric Pollution Research, 2, 283-299. https://doi.org/10.5094/APR.2011.035

[29] Mayfield, J.A. and Fochesatto, J. (2013) The Layered Structure of the Winter Atmospheric Boundary Layer in the Interior of Alaska. Journal of Applied Meteorology and Climatology, 52, 953-973. https://doi.org/10.1175/JAMC-D-12-01.1 